\title{
Cell survival and radiosensitisation: Modulation of the linear and quadratic parameters of the LQ model (Review)
}

\author{
NICOLAAS A.P. FRANKEN ${ }^{1}$, ARLENE L. OEI ${ }^{1}$, H. PETRA KOK ${ }^{1}$, HANS M. RODERMOND ${ }^{1}$, PETER SMINIA ${ }^{3}$, \\ JOHANNES CREZEE $^{1}$, LUKAS J.A. STALPERS ${ }^{1}$ and GERRIT W. BARENDSEN ${ }^{1,2}$ \\ ${ }^{1}$ Department of Radiotherapy, Laboratory for Experimental Oncology and Radiobiology (LEXOR), \\ Center for Molecular Medicine, ${ }^{2}$ Department of Cell Biology, Academic Medical Center (AMC), University \\ of Amsterdam; ${ }^{3}$ Department of Radiation Oncology, VU Medical Center, Amsterdam, The Netherlands
}

Received November 2, 2012; Accepted December 21, 2012

DOI: $10.3892 /$ ijo.2013.1857

\begin{abstract}
The linear-quadratic model (LQ model) provides a biologically plausible and experimentally established method to quantitatively describe the dose-response to irradiation in terms of clonogenic survival. In the basic LQ formula, the clonogenic surviving fraction $\mathrm{S}_{\mathrm{d}} / \mathrm{S}_{0}$ following a radiation dose $\mathrm{d}$ (Gy) is described by an inverse exponential approximation: $\mathrm{S}_{\mathrm{d}} / \mathrm{S}_{0}=\mathrm{e}^{-\left(\alpha \mathrm{d}+\beta \mathrm{d}^{2}\right)}$, wherein $\alpha$ and $\beta$ are experimentally derived parameters for the linear and quadratic terms, respectively. Radiation is often combined with other agents to achieve radiosensitisation. In this study, we reviewed radiation enhancement ratios of hyperthermia (HT), halogenated pyrimidines (HPs), various cytostatic drugs and poly(ADP-ribose) polymerase-1 (PARP1) inhibitors expressed in the parameters $\alpha$ and $\beta$ derived from cell survival curves of various mammalian cell cultures. A significant change in the $\alpha / \beta$ ratio is of direct clinical interest for the selection of optimal fractionation schedules in radiation oncology, influencing the dose per fraction, dose fractionation and dose rate in combined treatments. The $\alpha / \beta$ ratio may increase by a mutually independent increase of $\alpha$ or decrease of $\beta$. The results demonstrated that the different agents increased the values of both $\alpha$ and $\beta$. However, depending on culture conditions, both parameters can also be separately influenced. Moreover, it appeared that radiosensitisation was more effective in radioresistant cell lines than in radiosensitive cell lines. Furthermore, radiosensitisation is also dependent on the cell cycle stage, such as the plateau or exponentially growing phase, as well as on post-treatment plating conditions. The LQ model provides a useful tool in the quantification of the effects of radiosensitising agents. These insights will help optimize fractionation schedules in multimodality treatments.
\end{abstract}

Correspondence to: Dr Nicolaas A.P. Franken, Department of Radiotherapy, Laboratory for Experimental Oncology and Radiobiology (LEXOR), Center for Molecular Medicine, Academic Medical Centre, P.O. Box 22700, 1100 DE Amsterdam, The Netherlands

E-mail: n.a.franken@amc.uva.nl

Key words: linear-quadratic model, cell survival, radiosensitisation, hyperthermia, chemotherapeutic agents

\section{Contents}

1. Introduction

2. Hyperthermia

3. Cisplatin

4. Gemcitabine

5. Temozolomide

6. Halogenated pyrimidines

7. PARP1 inhibitors

8. Discussion

9. Conclusion

\section{Introduction}

The treatment of cancer by ionizing radiation is frequently combined with chemotherapy as well as with other agents, in an effort to increase effectiveness. The selection of these combinations has been considerably based on experimental studies with cells in culture and experimental tumours in animals. These studies were designed to obtain insights into the mechanisms of interaction and to derive quantitative information on potential methods of enhancing effectiveness, either through a decrease in cell survival in vitro or an increase in tumour response in vivo.

The results of experiments on combined treatments of cells or tumours are generally expressed in a single sensitisation or enhancement factor (ER), as calculated from dose-effect relationships for the endpoints assessed, following treatment with or without the combined agents. However, such a single sensitisation factor provides only part of the information that can be derived from the complete experimentally assessed dose-effect relationships. Different plating conditions were investigated. Cells were plated prior to irradiation or combined treatment (ppi), plated immediately after irradiation or combined treatment (ip) or plated with a 24-h delay (dp) to establish potentially lethal damage repair (PLDR).

Quantitative information derived from numerous studies on cultured cells, tumours and normal tissues in animals, can be conveniently analysed in terms of mathematical dose-effect relationships based on the linear-quadratic (LQ) model of cell reproductive death as a function of the radiation 
dose (1-4). The LQ formula for cell reproductive death, the surviving fraction $\left(\mathrm{S}_{\mathrm{d}}\right)$ of cells exposed to radiation dose $(\mathrm{d})$, compared to the survival of unirradiated cells $\left(\mathrm{S}_{0}\right)$ is described by an inverse exponential approximation: $\mathrm{S}_{\mathrm{d}} / \mathrm{S}_{0}=\mathrm{e}^{-\left(\alpha \mathrm{d}+\beta \mathrm{d}^{2}\right)}$ and contains two parameters, $\alpha\left(\mathrm{Gy}^{-1}\right)$ and $\beta\left(\mathrm{Gy}^{-2}\right)$. The initial slope of cell survival curves and the effectiveness at low doses is determined by $\alpha$, while $\beta$ represents the increasing contribution from cumulative damage, presumably due to the interaction of two or more lesions induced by separate ionizing radiations (1). DNA double-strand breaks (DSBs) are generally assumed to be the most relevant lesions.

The $\alpha / \beta$ ratio represents the dose at which the two terms contribute equally to the total effect. Data from numerous studies on cells, tumours and normal tissues have demonstrated that the values of $\alpha / \beta$ usually range between 3 and $10 \mathrm{~Gy}$. Since the dose fractions applied in cancer radiotherapy are mostly in the 1.5-2.5 Gy range, it seems clear that the clinical effect of radiotherapy on tumours is largely determined by the linear parameter $\alpha$.

However, in experimental studies on the enhancement of radiation treatments by chemical or physical agents, the enhancement ratios are typically calculated as the ratio of doses required to obtain equal effects at dose levels for which the effects can be most easily assessed experimentally, namely at doses between 5 and $10 \mathrm{~Gy}$. At these high-fraction doses, the effectiveness is largely determined by the quadratic term $\beta \mathrm{d}^{2}$ and not by the linear term $\alpha \mathrm{d}$. The common use of a single ER is based on the implicit assumption that any radiosensitiser changes both LQ parameters equally, although this assumption may not hold for all radiosensitising agents. It is therefore of interest to analyse enhancement factors for the linear and quadratic parameters separately, to evaluate their impact at the doses commonly applied in radiotherapy. The parameters $\alpha$ and $\beta$ were determined from survival curves using SPSS statistical software performing a fit to the data according to the LQ formula by multiple regression analysis.

In this review, radiosensitisation data from our own laboratory are presented and subsequently discussed and compared to the data from the literature. In a number of former studies conducted by our laboratory, radiation sensitisation by a variety of agents in different types of mammalian cells has been investigated and cell survival curves have been analysed using the LQ model (5-11). Radiation enhancement could thus be assessed in separate $\alpha$ - and $\beta$-values and in the $\alpha / \beta$ ratio. The results for various radiosensitising agents are presented in the following sections.

\section{Hyperthermia}

Radiosensitisation by hyperthermia. Hyperthermia (HT) refers to heat treatment of cancer cells or tumours by increasing the temperature to a level between 39 and $45^{\circ} \mathrm{C}$. It is used in combination with chemo- and/or radiotherapy and it is has been shown to enhance their anticancer effects experimentally and clinically (12-16). A number of in vitro studies on the combination of HT and radiation have demonstrated a synergistic interaction between the two modalities, particularly at higher temperatures $\left(>42^{\circ} \mathrm{C}\right)$ (17-19). This interaction possibly results from the inhibition of the repair of radiation-induced DNA damage by HT $(20,21)$. The sequence of combined radia- tion and HT treatment is important. Optimal sensitisation is achieved when radiation and HT are applied simultaneously or within a short time interval (22). Radiotherapy with concomitant HT is not always feasible in clinical practice. Therefore, in our experiments, HT was also applied sequentially, immediately following radiation treatment.

Despite the clinical goal to realise cytotoxic temperatures as high as $43^{\circ} \mathrm{C}$, in practice, tumour temperature distributions are heterogeneous. In large areas of the tumour, temperatures are often $<43^{\circ} \mathrm{C}$. Nonetheless, satisfactory results have been obtained in locally advanced cervical cancers treated with radiotherapy plus mild $\mathrm{HT}<43^{\circ} \mathrm{C}$ (13). Mild temperatures may have more subtle effects than high temperatures, such as tumour reoxygenation (23-26). We recently discovered that mild HT $\left(42^{\circ} \mathrm{C}\right.$ for $\left.1 \mathrm{~h}\right)$ transiently breaks down the BRCA2 protein (27). In the following sections, the effects of HT for $1 \mathrm{~h}$ at 41 or $43^{\circ} \mathrm{C}$ on the LQ parameters are summarized. Several different cell types have been studied.

Effect of HT on radiosensitivity of SiHa and RKO cells. The $\mathrm{SiHa}$ cell line is derived from a human cervical carcinoma. The cells were plated prior to treatment. Mild HT alone $\left(41^{\circ} \mathrm{C}\right.$ for $1 \mathrm{~h}$ ) had almost no effect and resulted in a surviving fraction of $0.95 \pm 0.2$. As can be observed in Fig. 1 and Table I, $1 \mathrm{~h}$ at $41.0^{\circ} \mathrm{C}$ exclusively enhanced the quadratic parameter, $\beta$, by a factor of 3.9. The value of the linear parameter, $\alpha$, was hardly influenced. HT treatment at $43^{\circ} \mathrm{C}$ for $1 \mathrm{~h}$ significantly increased the values of both parameters.

The RKO cell line, derived from a human colon cancer, is relatively sensitive to HT treatment. HT alone for $1 \mathrm{~h}$ at $43^{\circ} \mathrm{C}$ decreased the relative survival to $<0.01$ and combination with radiation doses in excess of $5 \mathrm{~Gy}$ always resulted in the complete absence of colony formation. Mild $\mathrm{HT}$ alone $\left(41^{\circ} \mathrm{C}\right.$ for $1 \mathrm{~h}$ ) had little effect and resulted in a surviving fraction of $0.8 \pm 0.4$ in immediately plated (ip) and of $0.9 \pm 0.1$ in delayed plated (dp) cells. When the cells were heated to $41^{\circ} \mathrm{C}$ for $1 \mathrm{~h}$ immediately prior to irradiation, a significant $(\mathrm{P}<0.001)$ enhancement of cellular radiosensitivity was observed in both ip (Fig. 1, left panel) and dp (Fig. 1, right panel) cells $(25,28)$.

The effects of HT on the LQ parameters are summarized in Table I. The value of $\alpha$ increased by a factor of 1.7 to 1.8 , while the value of $\beta$ increased by a factor as high as 2.5 to 7.0. One must bear in mind that the quadratic component $\beta \mathrm{d}^{2}$ in this cell line is quite small and small absolute changes can result in large relative changes of the numerical values of $\beta$.

Effect of HT on radiosensitivity of SW-1573 cells. SW-1573 cells are derived from a human lung tumour and are much less sensitive to HT than RKO cells. Studies have been carried out to evaluate whether pre-treatment with HT at 41 or $43^{\circ} \mathrm{C}$ can enhance the radiosensitivity of SW-1573 cells (25). HT at $41^{\circ} \mathrm{C}$ for $1 \mathrm{~h}$ without irradiation did not result in a further decrease of the surviving fraction for ip and dp cells, compared to irradiation alone. One-hour HT at $43^{\circ} \mathrm{C}$ decreased survival to $0.5 \pm 0.1$ for ip and to $0.4 \pm 0.2$ for dp cells. Pre-treatment of cells at $41^{\circ} \mathrm{C}$ for $1 \mathrm{~h}$ did not affect cellular radiosensitivity of either ip or $\mathrm{dp}$ cells (Fig. 2, left panel). However, 1-h treatment at $43^{\circ} \mathrm{C}$ resulted in a significant radiation enhancement in both ip and dp cells ( $<<0.001$; Fig. 2, right panel). In Table I, the values of the LQ parameters for radiation alone and for combined treatments 
Table I. Values of the linear-quadratic parameters $\alpha$ and $\beta, \alpha / \beta$ ratio and enhancement factors from cells treated with ionizing radiation only and following combined radiation and hyperthermia (HT) treatment.

\begin{tabular}{llllcll}
\hline Cells & $\begin{array}{l}\text { Treatment } \\
{ }^{\circ} \mathrm{C}(\mathrm{h})\end{array}$ & $\begin{array}{l}\alpha\left(\mathrm{Gy}^{-1}\right) \\
\text { control }\end{array}$ & $\begin{array}{l}\beta\left(\mathrm{Gy}{ }^{-2}\right) \\
\text { control }\end{array}$ & $\alpha / \beta$ & $\alpha$-EF & $\beta$-EF \\
\hline \multirow{2}{*}{ SiHa ppi } & Sham & $0.33 \pm 0.06$ & $0.02 \pm 0.01$ & $13.8 \pm 6.2$ & & \\
& HT 41 (1) & $0.31 \pm 0.05$ & $0.09 \pm 0.02$ & $3.3 \pm 0.7$ & $0.9 \pm 0.2$ & $3.9 \pm 1.6$ \\
\multirow{2}{*}{ RKO ip } & HT 43 (1) & $0.76 \pm 0.04$ & $0.09 \pm 0.01$ & $8.7 \pm 0.8$ & $1.4 \pm 0.1$ & $2.7 \pm 0.5$ \\
& Sham & $0.55 \pm 0.09$ & $0.02 \pm 0.01$ & $27.5 \pm 14.1$ & & \\
RKO dp & HT 41 (1) & $0.93 \pm 0.09^{\mathrm{a}}$ & $0.05 \pm 0.02$ & $18.6 \pm 7.7$ & $1.7 \pm 0.3$ & $2.5 \pm 1.6$ \\
& Sham & $0.47 \pm 0.09$ & $0.01 \pm 0.01$ & $47.0 \pm 47.6^{\mathrm{b}}$ & & \\
SW-1573 ip & HT 41 (1) & $0.83 \pm 0.08^{\mathrm{a}}$ & $0.07 \pm 0.02$ & $11.9 \pm 3.6$ & $1.8 \pm 0.4$ & $7.0 \pm 7.3$ \\
& Sham & $0.21 \pm 0.02$ & $0.06 \pm 0.02$ & $3.5 \pm 1.2$ & & \\
& HT 41 (1) & $0.06 \pm 0.02$ & $0.11 \pm 0.03$ & $0.6 \pm 0.2$ & $0.3 \pm 0.1$ & $1.8 \pm 0.8$ \\
SW-1573 dp & HT 43 (1) & $0.49 \pm 0.04^{\mathrm{a}}$ & $0.12 \pm 0.03$ & $4.1 \pm 1.1$ & $2.3 \pm 0.3$ & $2.0 \pm 0.8$ \\
& Sham & $0.09 \pm 0.02$ & $0.06 \pm 0.02$ & $1.5 \pm 1.6$ & & \\
& HT 41 (1) & $0.05 \pm 0.02$ & $0.08 \pm 0.02$ & $0.6 \pm 0.6$ & $0.6 \pm 0.3$ & $1.3 \pm 0.6$ \\
& HT 43 (1) & $0.40 \pm 0.04^{\mathrm{a}}$ & $0.11 \pm 0.03$ & $3.6 \pm 1.1$ & $4.4 \pm 1.1$ & $1.8 \pm 0.8$ \\
\hline
\end{tabular}

Sham, control (radiation only); ppi, plating prior to irradiation; ip, immediately plated; dp, delayed plated. ${ }^{a}$ Significant from sham $\mathrm{P}<0.05$. ${ }^{\mathrm{b}} \mathrm{The}$ $\alpha / \beta$ has a large variation due to the high uncertainty of the $\beta$-value. EF, enhancement factor.


Figure 1. Radiation dose-survival curves of confluent cultures of RKO cells (human colon cancer cells) plated immediately after irradiation (ip, left panel) or $24 \mathrm{~h}$ after irradiation (dp, right panel), with or without hyperthermia pre-treatment at $41^{\circ} \mathrm{C}$ for $1 \mathrm{~h}$. Means with standard errors of at least three experiments are shown.
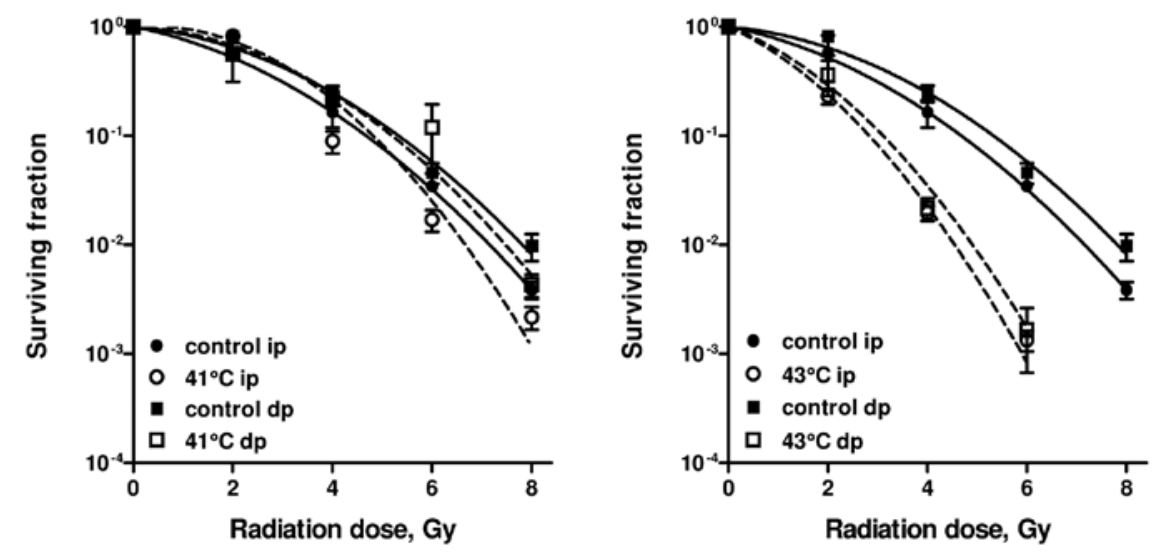

Figure 2. Radiation dose-survival curves of confluent cultures of SW-1573 cells (human lung tumour cells) plated immediately after irradiation (ip) or $24 \mathrm{~h}$ after irradiation (dp), with or without hyperthermia pre-treatment at $41^{\circ} \mathrm{C}$ (left panel) or at $43^{\circ} \mathrm{C}$ (right panel) for $1 \mathrm{~h}$. Means with standard errors of at least three experiments are shown. 
are summarised. HT for $1 \mathrm{~h}$ at $41^{\circ} \mathrm{C}$ resulted in an increase of the $\beta$-value by a factor of 1.3 to 1.8 , while the $\alpha$-value was decreased. HT treatment for $1 \mathrm{~h}$ at $43^{\circ} \mathrm{C}$ resulted in an increase of the $\alpha$-value by a factor of 2.3 to 4.4 , while the $\beta$-value was increased by a factor of 1.8 to 2.0 .

\section{Cisplatin}

Cisplatin is a widely used anticancer drug that is often combined with radiotherapy (29). Cisplatin-based chemoradiotherapy has become standard treatment for, among others, locally advanced cervical carcinoma (30) and locally advanced non-small-cell lung cancer (NSCLC) (31). There have been numerous studies on the radiation-sensitising effect of cisplatin; however, the results vary from a clear cisplatin-induced radiosensitisation $(24,25,32-34)$ to a merely additive effect on cell survival (35). Cisplatin and radiation share a common cellular target, DNA (36).

Cisplatin causes DNA damage by inducing the formation of inter- and intrastrand adducts (37). The cisplatin-DNA adducts may cause cell cycle arrest, inhibition of DNA replication and transcription and eventually, apoptosis (38). Repair inhibition of DNA has also been implicated (39). The most important repair pathways reported to be involved in cisplatin-induced DNA damage repair are nucleotide excision repair (NER) and/or homologous recombination (HR) $(40,41)$. An additional route for the repair of cisplatin-DNA interstrand adducts is the post-replication/translation repair pathway which assists the cell in tolerating or bypassing the lesion (42).

Irradiation causes repairable (potentially lethal) and non-repairable (lethal) DNA lesions, which are independently induced. The ultimate effect of the repairable lesions depends on the competing processes of repair and misrepair. The PLDR is reflected by the difference in survival between ip and dp cells. The inhibition of PLDR has been implicated in cisplatin-induced radiation sensitisation (25). More specifically, cisplatin-induced radiation sensitisation is caused by the inhibition of the non-homologous end joining (NHEJ) pathway and recombination repair $(38,40,43)$.

In this section, the radiation sensitisation of cisplatin on the SW-1573 lung tumour cell line and the SiHa cervical tumour cell line is quantified by changes in the LQ parameters (25). Survival curves for SW-1573 lung tumour cells following radiation alone and radiation combined with cisplatin $(1 \mu \mathrm{M}$ for $1 \mathrm{~h})$ are presented in Fig. 3. Cisplatin was added to the cultures immediately prior to irradiation. The survival curves were obtained directly (ip) and $24 \mathrm{~h}$ after (dp) treatment to determine PLDR. A slight, but statistically significant effect of cisplatin on radiosensitivity was only observed in the dp cells $(\mathrm{P}=0.02)$. This was also described by an increase in the $\alpha$ - and $\beta$-values (Table II). An increase in the $\alpha$-value by a factor of 2.5 was achieved in the dp cells by cisplatin treatment, whereas an increase in the $\beta$-value by a factor of 1.2 was observed under both plating conditions. The effects on the LQ parameters of different plating conditions, 1-h incubation with 1 or $5 \mu \mathrm{M}$ cisplatin and continuous incubation with cisplatin during the complete duration of the clonogenic assay, are also presented in Table II. The radiosensitizing effects are more evident in the SiHa cervical tumour cell line with $1 \mu \mathrm{M}$ continous cisplatin incubation compared to the SW-1573 lung tumour cell line.

\section{Gemcitabine}

Gemcitabine (dFdC, difluorodeoxycytidine) is a deoxycytidine analogue with clinical activity in NSCLC and pancreatic cancer (44-47). It requires phosphorylation to its active metabolites, gemcitabine-diphosphate (dF-dCDP) and gemcitabine-triphosphate (dF-dCTP), with the initial phosphorylation by deoxycytidine kinase (dCK) being the rate-limiting step $(48,49)$. $\mathrm{dF}-\mathrm{dCTP}$ inhibits ribonucleotide reductase, the enzyme regulating the production of deoxynucleotides, which are necessary for DNA synthesis and repair (50). Deoxynucleotide depletion leads to the increased incorporation of dF-dCTP into DNA, thereby blocking DNA synthesis (masked chain termination). Following the incorporation of dF-dCTP into DNA, an increase in the number of DNA single-strand breaks (SSBs), chromosome breaks and micronuclei has been observed (51).

In vitro and in vivo studies have demonstrated that gemcitabine is a potent radiosensitiser (39,49,52-59). However, in a previous study on NSCLC patients, radiotherapy with concurrent gemcitabine resulted in unacceptable pulmonary toxicity, due to the large amount of radiation delivered to the lungs (60). Phase I trials have demonstrated that radiotherapy combined with gemcitabine at lower doses is feasible without severe pulmonary toxicity $(45,61)$. Its unique mechanism of action, lack of overlapping toxicity and favourable toxicity profile make gemcitabine an ideal candidate for combination therapy (45). There are numerous ongoing randomized studies in which radiotherapy is combined with gemcitabine.

Gemcitabine radiosensitisation has been investigated in gemcitabine-sensitive and -resistant human lung tumour cells, SWp and SWg, respectively, as well as in gemcitabine-sensitive and -resistant human ovarian tumour cells, A2780 and AG6000, respectively (62-64). Gemcitabine was administered $24 \mathrm{~h}$ prior to radiation treatment (64). The SWp cell line is similar to the SW-1573 cell line described above. It is termed SWp to distinguish it from SWg, the gemcitabine-resistant counterpart which was developed by van Bree et al (64). Lung tumour cells exhibit different sensitivities to radiation alone as compared to ovarian cancer cells (62-64).

Table III summarizes the LQ parameters of the different cell lines obtained following analyses of the radiation dose-survival curves for irradiation alone and following combined irradiation and gemcitabine. SWp and SWg cells were almost equally sensitive to ionizing radiation alone with respect to the low-dose region described by the $\alpha$-value. A slight increase in survival was observed in the SWg cells under the high-radiation dose region ( $>4 \mathrm{~Gy}$ ), which was reflected by a slightly lower $\beta$-value $(0.040 \pm 0.006$ vs. $0.055 \pm 0.008)$. The A2780 human ovarian carcinoma cell line and its gemcitabine-resistant variant, AG6000, were equally sensitive to ionizing radiation. The surviving fractions of the different cell lines following incubation with gemcitabine alone were as follows: SWp cells: $10 \mathrm{nM}, 0.52 \pm 0.06$; SWg cells: $10 \mu \mathrm{M}$, $0.95 \pm 0.03$; $100 \mu \mathrm{M}, 0.24 \pm 0.11$; A2780 cells: $2 \mathrm{nM}, 0.82 \pm 0.08$; $10 \mathrm{nM}, 0.21 \pm 0.08$; AG6000 cells: $20 \mu \mathrm{M}, 0.62 \pm 0.07 ; 50 \mu \mathrm{M}$, $0.22 \pm 0.04$.

As depicted in Fig. 4 and Table III, radiosensitisation is observed in both gemcitabine-sensitive and gemcitabineresistant cells. However, much higher gemcitabine doses were 
Table II. Values of the linear-quadratic parameters $\alpha$ and $\beta, \alpha / \beta$ ratio and enhancement factors from SW-1573 and SiHa cells treated with ionizing radiation only and following combined radiation and cisplatin $(1 \mu \mathrm{M}$ for $1 \mathrm{~h} ; 1 \mu \mathrm{M}$ continuously; $5 \mu \mathrm{M}$ continuously) treatment.

\begin{tabular}{|c|c|c|c|c|c|c|}
\hline Cells & Treatment & $\begin{array}{l}\alpha\left(\mathrm{Gy}^{-1}\right) \\
\text { control }\end{array}$ & $\begin{array}{l}\beta\left(\mathrm{Gy}^{-2}\right) \\
\text { control }\end{array}$ & $\alpha / \beta$ & $\alpha-E F$ & $\beta-E F$ \\
\hline SW-1573 ip & $\begin{array}{l}\text { Sham } \\
1 \mu \mathrm{M} \text { cisplatin }(1 \mathrm{~h})\end{array}$ & $\begin{array}{l}0.21 \pm 0.09 \\
0.21 \pm 0.08\end{array}$ & $\begin{array}{l}0.061 \pm 0.016 \\
0.072 \pm 0.018\end{array}$ & $\begin{array}{l}3.4 \pm 1.7 \\
2.9 \pm 1.3\end{array}$ & $1.0 \pm 0.6$ & $1.2 \pm 0.4$ \\
\hline SW-1573 dp & $\begin{array}{l}\text { Sham } \\
1 \mu \mathrm{M} \text { cisplatin }(1 \mathrm{~h})\end{array}$ & $\begin{array}{l}0.10 \pm 0.09 \\
0.25 \pm 0.09^{\mathrm{a}}\end{array}$ & $\begin{array}{l}0.063 \pm 0.016 \\
0.077 \pm 0.017\end{array}$ & $\begin{array}{l}1.6 \pm 1.5 \\
3.3 \pm 1.4\end{array}$ & $2.5 \pm 2.4$ & $1.2 \pm 0.4$ \\
\hline SW-1573 ppi & $\begin{array}{l}\text { Sham } \\
1 \mu \mathrm{M} \text { cisplatin (cont) } \\
5 \mu \mathrm{M} \text { cisplatin (cont) }\end{array}$ & $\begin{array}{l}0.37 \pm 0.12 \\
0.41 \pm 0.08 \\
0.58 \pm 0.20^{\mathrm{a}}\end{array}$ & $\begin{array}{l}0.014 \pm 0.034 \\
0.019 \pm 0.025 \\
0.030 \pm 0.008^{\mathrm{a}}\end{array}$ & $\begin{array}{l}26.4 \pm 64.8^{b} \\
21.6 \pm 28.7^{b} \\
19.3 \pm 8.4\end{array}$ & $\begin{array}{l}1.1 \pm 0.4 \\
1.6 \pm 0.7\end{array}$ & $\begin{array}{l}1.4 \pm 3.8 \\
2.1 \pm 5.2\end{array}$ \\
\hline SiHa ppi & $\begin{array}{l}\text { Sham } \\
1 \mu \mathrm{M} \text { cisplatin (cont) }\end{array}$ & $\begin{array}{l}0.41 \pm 0.04 \\
0.81 \pm 0.12^{\mathrm{a}}\end{array}$ & $\begin{array}{l}0.01 \pm 0.01 \\
0.02 \pm 0.02\end{array}$ & $\begin{array}{l}41.0 \pm 41.2^{\mathrm{b}} \\
40.5 \pm 41.0^{\mathrm{b}}\end{array}$ & $2.0 \pm 0.4$ & $2.0 \pm 2.8$ \\
\hline
\end{tabular}

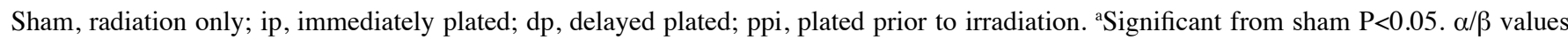
show that in SW-1573 cells the quadratic term is affected more than the linear term, while in SiHa cells only the linear term is significantly increased. ${ }^{b}$ The $\alpha / \beta$ has a large variation due to the high uncertainty of the $\beta$-value. EF, enhancement factor; cont, continuously.

Table III. Values of the linear-quadratic parameters $\alpha$ and $\beta, \alpha / \beta$ ratio and enhancement factors from cells treated with ionizing radiation only and gemcitabine-sensitised radiation dose-survival curves of gemcitabine-sensitive (SWp and A2780) and gemcitabine-resistant (SWg and AG6000) cells.

\begin{tabular}{|c|c|c|c|c|c|c|}
\hline Cells & Treatment & $\begin{array}{l}\alpha\left(\mathrm{Gy}^{-1}\right) \\
\text { control }\end{array}$ & $\begin{array}{l}\beta\left(\mathrm{Gy}^{-2}\right) \\
\text { control }\end{array}$ & $\alpha / \beta$ & $\alpha-E F$ & $\beta-\mathrm{EF}$ \\
\hline SWp & $\begin{array}{l}\text { Sham } \\
10 \mathrm{nM} \text { gemcitabine }\end{array}$ & $\begin{array}{l}0.10 \pm 0.03 \\
0.30 \pm 0.06^{\mathrm{a}}\end{array}$ & $\begin{array}{l}0.055 \pm 0.008 \\
0.053 \pm 0.007\end{array}$ & $\begin{array}{l}1.8 \pm 0.6 \\
5.7 \pm 1.4\end{array}$ & $3.0 \pm 2.8$ & $0.96 \pm 0.2$ \\
\hline SWg & $\begin{array}{l}\text { Sham } \\
100 \mu \mathrm{M} \text { gemcitabine }\end{array}$ & $\begin{array}{l}0.09 \pm 0.02 \\
0.09 \pm 0.03\end{array}$ & $\begin{array}{l}0.040 \pm 0.006 \\
0.090 \pm 0.041^{\mathrm{b}}\end{array}$ & $\begin{array}{l}2.3 \pm 0.6 \\
1.0 \pm 0.6\end{array}$ & $1.0 \pm 0.5$ & $2.3 \pm 1.1$ \\
\hline A 2780 & $\begin{array}{l}\text { Sham } \\
10 \mathrm{nM} \text { gemcitabine }\end{array}$ & $\begin{array}{l}0.80 \pm 0.10 \\
1.10 \pm 0.15^{\mathrm{a}}\end{array}$ & $\begin{array}{l}\mathrm{Na} \\
\mathrm{Na}\end{array}$ & & $1.4 \pm 0.3$ & \\
\hline AG6000 & $\begin{array}{l}\text { Sham } \\
50 \mu \mathrm{M} \text { gemcitabine }\end{array}$ & $\begin{array}{l}0.83 \pm 0.13 \\
1.11 \pm 0.20^{\mathrm{b}}\end{array}$ & $\begin{array}{l}\mathrm{Na} \\
\mathrm{Na}\end{array}$ & & $1.3 \pm 0.3$ & \\
\hline
\end{tabular}

Significant difference with ${ }^{\mathrm{a}} \mathrm{P}<0.01$; ${ }^{\mathrm{b}} \mathrm{P}<0.05$; Na, not applicable. $\mathrm{EF}$, enhancement factor.
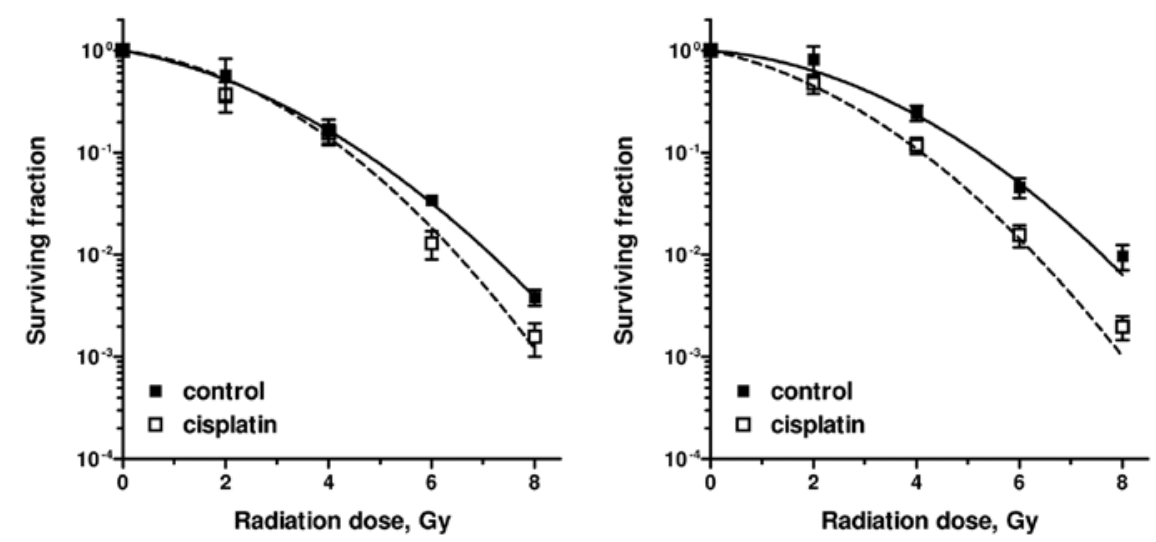

Figure 3. Radiation dose-survival curves of confluent cultures of SW-1573 cells plated immediately after irradiation, (ip, left panel) or $24 \mathrm{~h}$ after irradiation, (dp, right panel), with or without $1 \mu \mathrm{M}$ cisplatin treatment for $1 \mathrm{~h}$. Means with standard errors of at least three experiments are shown. 

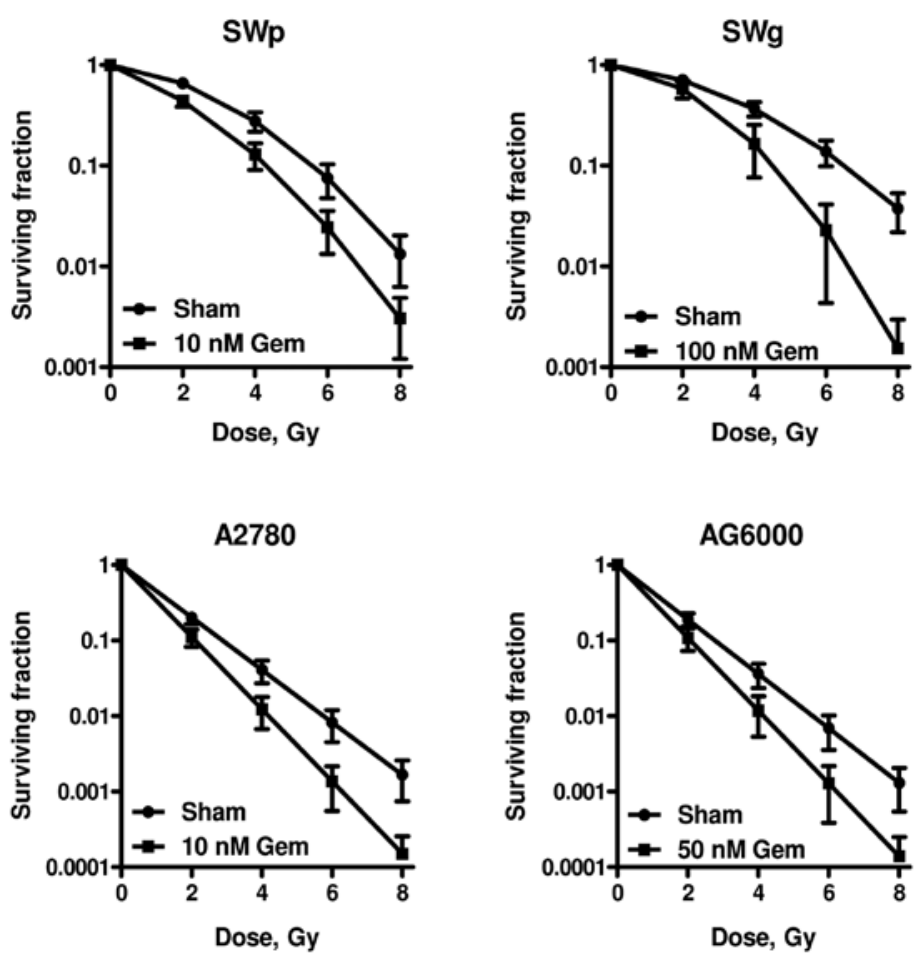

Figure 4. Radiation sensitisation following a 24-h incubation with different concentrations of gemcitabine in gemcitabine-sensitive SWp and -resistant SWg lung tumour cells and in gemcitabine-sensitive A2780 and -resistant AG6000 ovarian cancer cells. Surviving fractions are corrected for gemcitabine toxicity alone (for values see text). Cells are plated immediately after irradiation. Means with SEM of at least three separate experiments are shown.

required for the radiation sensitisation of gemcitabine-resistant cells to result in similar cytotoxicity. Both gemcitabine-sensitive cell lines (SWp and A2780) were sensitised by incubation with $10 \mathrm{nM}$ of gemcitabine for $24 \mathrm{~h}$ prior to irradiation, while the SWg and AG6000 cell lines were not radiosensitised by this dose of gemcitabine. Radiosensitisation of the two gemcitabine-sensitive cell lines was reflected by an increase in the $\alpha$-values by a factor of 3 and 1.4, respectively, whereas the $\beta$-values were not significantly altered. Higher concentrations of gemcitabine ( 50 and $100 \mathrm{nM}$ ) were required to sensitise the gemcitabine-resistant AG6000 and SWg cells to irradiation. For the SWg cells, the radiosensitisation was reflected by an increase in the $\beta$-value by a factor of 2.25 in, whereas in the AG6000 cells, only the $\alpha$-value was increased by a factor of 1.3 .

\section{Temozolomide}

The combination of fractionated radiotherapy with temozolomide (TMZ) has significantly improved the survival of patients with newly diagnosed glioblastoma multiforme (GBM) $(65,66)$. The combination of radiotherapy and TMZ has become standard therapy for GBM patients. The benefits of TMZ are most prominent for tumours with a methylated $\mathrm{O}^{6}$-methylguanine-DNA methyltransferase (MGMT) promoter: methylation of the MGMT promoter has been associated with a longer overall survival of GBM patients treated with radiotherapy and TMZ, compared to radiotherapy alone $(67,68)$. Van Nifterik et al (10) demonstrated a relatively lower cell survival in methylated GBM cell lines following treatment with radiotherapy and TMZ, which suggests an interaction between TMZ and irradiation.
TMZ is a chemotherapeutic prodrug that transforms under physiological conditions into its active unstable methylating metabolite, 5-(3-methyl-1-triazeno)imidazole4-carboxamide (MTIC). Methylation of DNA by MTIC results in the formation of $\mathrm{O}^{6}$-methylguanine adducts. These adducts are considered to be responsible for the cytotoxic effects of TMZ $(69,70)$. $\mathrm{O}^{6}$-methylguanine adducts can result in failure of the mismatch repair system, leading to DNA double-strand breakage and eventually, cell death $(71,72)$.

$\mathrm{O}^{6}$-methylguanine-DNA methyltransferase is a cytoprotective DNA repair protein that can remove the methyl group from the $\mathrm{O}^{6}$ position of guanine. Therefore, presence of this repair protein may undo, in part, the cytotoxic effect of alkylating agents, hence resulting in tumour resistance to TMZ $(73,74)$. Hypermethylation of the $\mathrm{CpG}$ islands in the promoter region of the MGMT gene has been found to be associated with transcriptional silencing $(74,75)$ and, subsequently, with a good clinical response to alkylating agents in glioma patients $(76,77)$.

Few studies have been published on the radiosensitising potential of TMZ for glioma cell lines using different treatment protocols. In certain cell lines, an enhancement of the radiation effect has been demonstrated, whereas other cell lines have shown no interaction, but merely an additive effect (78-83).

In this review, we present the results of combined TMZ-radiation treatment on three long-term primary TMZ-sensitive glioma cell lines (Table IV). These three cell lines contain a MGMT promoter region that is for the most part, methylated and do not express the MGMT protein $(10,84,85)$.

The cells were exposed to isotoxic doses of TMZ for $96 \mathrm{~h}$ prior to $\gamma$-irradiation. A significant radiosensitising effect $(\mathrm{P}<0.05)$ of TMZ was demonstrated in the AMC-3046 glioma 
Table IV. Values of the linear-quadratic parameters $\alpha$ and $\beta, \alpha / \beta$ ratio and enhancement factors from cells treated with ionizing radiation only and temozolomide-sensitised radiation dose-survival curves of three glioma cell lines AMC-3046, VU-109 and VU-122 with different sensitivities to temozolomide (10).

\begin{tabular}{llcccc}
\hline Cell line & Treatment & $\alpha\left(\mathrm{Gy}^{-1}\right)$ & $\left.\beta(\mathrm{Gy})^{-2}\right)$ & $\alpha / \beta(\mathrm{Gy})$ & $\alpha-\mathrm{EF}$ \\
\hline \multirow{2}{*}{ AMC-3046 } & Sham & $0.014 \pm 0.033$ & $0.065 \pm 0.007$ & $0.22 \pm 0.06$ & $30.7 \pm 7.5$ \\
& Temozolomide & $0.43 \pm 0.025^{\mathrm{a}}$ & $0.009 \pm 0.005$ & $47.6 \pm 26.7$ & $0.14 \pm 0.8$ \\
\multirow{2}{*}{ VU-109 } & Sham & $0.14 \pm 0.031$ & $0.037 \pm 0.006$ & $3.8 \pm 1.0$ & $1.4 \pm 0.4$ \\
& Temozolomide & $0.19 \pm 0.038$ & $0.032 \pm 0.008$ & $6.0 \pm 1.9$ & $0.9 \pm 0.3$ \\
VU-122 & Sham & $0.11 \pm 0.025$ & $0.063 \pm 0.005$ & $1.8 \pm 0.4$ & $1.9 \pm 0.6$ \\
& Temozolomide & $0.21 \pm 0.047^{\mathrm{b}}$ & $0.067 \pm 0.010$ & $3.1 \pm 0.8$ & $1.1 \pm 0.2$ \\
\hline
\end{tabular}

Significant difference with ${ }^{\mathrm{P}}<0.01,{ }^{\mathrm{b}} \mathrm{P}<0.05$. EF, enhancement factor.
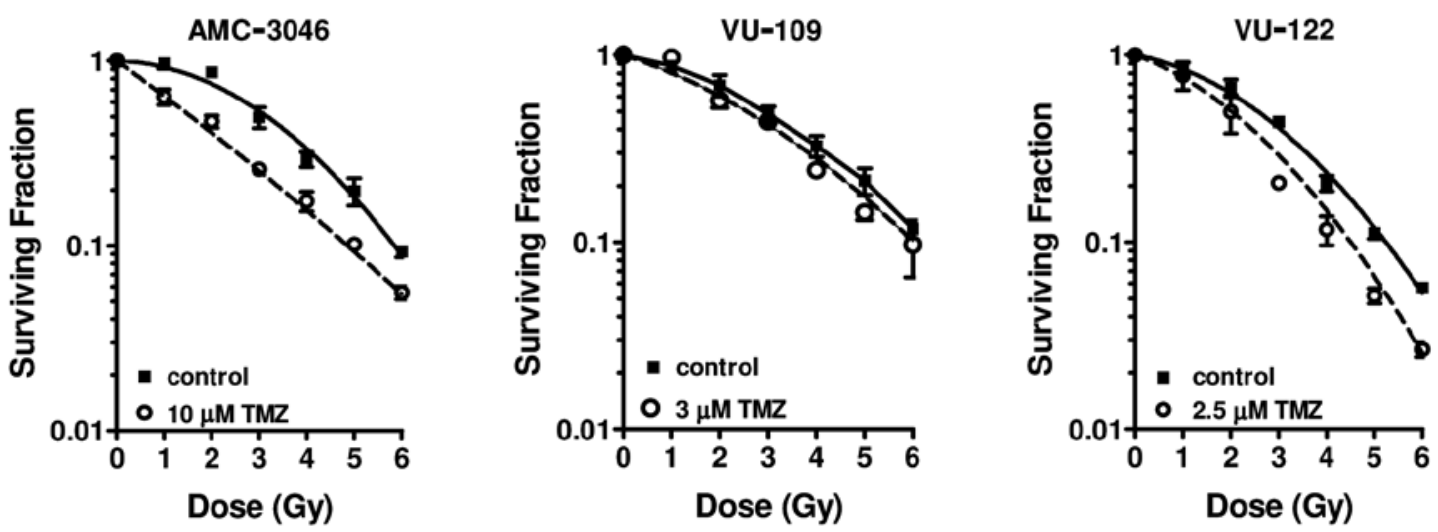

Figure 5. Radiation dose-survival curves of glioblastoma cells AMC-3046, VU-109 and VU-122 without (closed symbols) or with (open symbols) incubation with temozolomide (TMZ). Cells were incubated with $10 \mu \mathrm{M}$ (AMC-3046), $3 \mu \mathrm{M}$ (VU109) and $2.5 \mu \mathrm{M}$ (VU-122) TMZ for $96 \mathrm{~h}$ (daily refreshed) followed by irradiation.

cell line (Fig. 5, left panel). The shoulder of the survival curve for irradiated cells disappeared as a result of pre-treatment with TMZ. This was also reflected by TMZ-induced changes in both the $\alpha$ and $\beta$ parameters of the LQ model (Table IV). No radiosensitisation was observed in the VU-109 glioma cells ( $\mathrm{P}=0.054$; Fig. 5 , middle panel), as demonstrated by the unaffected $\alpha$ and $\beta$ parameters (Table IV). The VU-122 glioma cells displayed a small but significant radiosensitising effect of TMZ ( $\mathrm{P}<0.05$; Fig. 5, right panel), which was most obvious in the lower-radiation dose range. This difference was reflected by an increase in the $\alpha$ parameter without any change in the $\beta$ parameter (Table IV).

\section{Halogenated pyrimidines}

Incorporation of halogenated pyrimidines (HPs), chloro-, bromo- and iodo-deoxyuridine (CldUrd, BrdUrd, IdUrd) into DNA is known to sensitise cells to ionizing radiation $(6,8,11,86-93)$. The induced radiosensitisation increases with the degree of thymidine replacement. The mechanism of radiosensitisation by the HPs has been suggested to be due to an increase in the amount of DNA damage induced by radiation, an influence on repair of sublethal damage (SLD), or an enhanced expression of potentially lethal damage (PLD) $(6,94)$.
Since different processes are involved in these phenomena, several mechanisms may contribute to the radiosensitisation.

HPs have been suggested to provide an advantage in radiotherapy as radiosensitisers of cells in rapidly growing tumours, particularly under clinical conditions in which critical normal tissues show limited proliferation, and as a consequence, take up less HP. Labelling depends on the growth fraction, cell loss, cell cycle time and potential doubling time. Of particular importance for sensitisation is the rate at which non-cycling cells are recruited into the proliferative compartment during exposure to HPs and a course of radiotherapy. However, even in rapidly growing tumours, cells may, following proliferative cycles, retreat into a non-proliferative state. This may compromise the degree of radiation sensitisation, since resting cells are less affected by HPs, or are better able to cope with additional damage by PLDR.

In this review, we present the results of radiosensitisation following incubation with $4 \mu \mathrm{M}$ of IdUrd for $72 \mathrm{~h}$. IdUrd-induced radiosensitisation was observed in all the studied cell lines, SW-1573, RUCII (rat ureteral carcinoma), R1 (rat rhabdomyosarcoma) and V79 (Chinese hamster lung cells), in exponentially growing and in plateau-phase cells. Values of $\alpha$ and $\beta$ derived by LQ analysis of the survival curves of exponentially growing and plateau-phase cells are summarized in Table V. 
Table V. Values of the linear-quadratic parameters $\alpha$ and $\beta, \alpha / \beta$ ratio and enhancement factors of several cell lines treated with ionizing radiation only and after sensitisation with iododeoxyuridine (IdUrd) (incubation with $4 \mu \mathrm{M}$ of IdUrd for $72 \mathrm{~h}$ ).

\begin{tabular}{|c|c|c|c|c|c|c|c|c|}
\hline Cell line & $\begin{array}{l}\alpha\left(\mathrm{Gy}^{-1}\right) \\
\text { control }\end{array}$ & $\begin{array}{l}\beta\left(\mathrm{Gy}^{-2}\right) \\
\text { control }\end{array}$ & $\begin{array}{c}\alpha\left(\mathrm{Gy}^{-1}\right) \\
\text { IdUrd-sens }\end{array}$ & $\begin{array}{c}\beta\left(\mathrm{Gy}^{-2}\right) \\
\text { IdUrd-sens }\end{array}$ & $\begin{array}{c}\alpha / \beta \\
\text { control }\end{array}$ & $\begin{array}{c}\alpha / \beta \\
\text { IdUrd-sens }\end{array}$ & $\alpha-E F$ & $\beta-\mathrm{EF}$ \\
\hline $\begin{array}{l}\text { SW-1573 cells } \\
\text { Exp growing ip }\end{array}$ & $0.22 \pm 0.01$ & $0.022 \pm 0.001$ & $0.83 \pm 0.06$ & $\mathrm{Na}$ & $10.0 \pm 0.6$ & $\mathrm{Na}$ & $3.8 \pm 0.3$ & $\mathrm{Na}$ \\
\hline $\begin{array}{l}\text { SW- } 1573 \text { cells } \\
\text { Plateau-phase ip }\end{array}$ & $0.17 \pm 0.03$ & $0.042 \pm 0.004$ & $0.31 \pm 0.03$ & $0.047 \pm 0.005$ & $4.1 \pm 0.8$ & $6.6 \pm 1.0$ & $1.8 \pm 0.4$ & $1.1 \pm 0.2$ \\
\hline $\begin{array}{l}\text { SW-1573 cells } \\
\text { Plateau-phase dp }\end{array}$ & $0.09 \pm 0.02$ & $0.046 \pm 0.002$ & $0.37 \pm 0.04$ & $0.033 \pm 0.006$ & $2.0 \pm 0.4$ & $11.2 \pm 2.4$ & $4.1 \pm 1.0$ & $0.7 \pm 0.1$ \\
\hline $\begin{array}{l}\text { RUCII cells } \\
\text { Exp growing ppi }\end{array}$ & $0.008 \pm 0.007$ & $0.025 \pm 0.001$ & $0.06 \pm 0.02$ & $0.026 \pm 0.001$ & $0.3 \pm 0.3$ & $2.3 \pm 0.8$ & $7.5 \pm 7.0$ & $1.0 \pm 0.1$ \\
\hline $\begin{array}{l}\text { R1 cells } \\
\text { Exp growing ppi }\end{array}$ & $0.23 \pm 0.01$ & $0.068 \pm 0.003$ & $0.44 \pm 0.05$ & $0.075 \pm 0.016$ & $3.4 \pm 0.2$ & $5.9 \pm 1.4$ & $1.9 \pm 0.3$ & $1.1 \pm 0.2$ \\
\hline $\begin{array}{l}\text { V79 cells } \\
\text { Exp growing ip }\end{array}$ & $0.18 \pm 0.02$ & $0.017 \pm 0.003$ & $0.38 \pm 0.04$ & $0.023 \pm 0.007$ & $10.6 \pm 2.2$ & $16.5 \pm 5.3$ & $2.1 \pm 0.3$ & $1.4 \pm 0.5$ \\
\hline $\begin{array}{l}\text { V79 cells } \\
\text { Exp growing ppi }\end{array}$ & $0.15 \pm 0.02$ & $0.013 \pm 0.003$ & $0.29 \pm 0.03$ & $0.016 \pm 0.004$ & $11.5 \pm 3.1$ & $18.1 \pm 4.9$ & $1.9 \pm 0.3$ & $1.2 \pm 0.4$ \\
\hline $\begin{array}{l}\text { V79 cells } \\
\text { Plateau-phase ip }\end{array}$ & $0.09 \pm 0.03$ & $0.026 \pm 0.004$ & $0.17 \pm 0.02$ & $0.062 \pm 0.005$ & $3.5 \pm 1.3$ & $2.7 \pm 0.4$ & $1.9 \pm 0.7$ & $2.4 \pm 0.4$ \\
\hline $\begin{array}{l}\text { V79 cells } \\
\text { Plateau-phase dp }\end{array}$ & $0.07 \pm 0.02$ & $0.020 \pm 0.002$ & $0.30 \pm 0.03$ & $0.024 \pm 0.004$ & $3.5 \pm 1.1$ & $12.5 \pm 2.4$ & $4.3 \pm 1.3$ & $1.2 \pm 0.2$ \\
\hline
\end{tabular}

Means with SEM of at least three separate experiments are shown. ip, immediately plated after irradiation; dp, delayed plated after irradiation; ppi, plated prior to irradiation; Na, not applicable. EF, enhancement factor; IdUrd-sens, sensitisation with iododeoxyuridine; Exp growing, exponentially growing.


Figure 6. Radiation dose-survival curves of exponentially growing cells (left) without IdUrd (open triangles) and after incubation with $4 \mu \mathrm{M}$ IdUrd (closed triangles) and plateau-phase cells (right) plated immediately after irradiation (dashed lines) and plated $24 \mathrm{~h}$ after irradiation (solid lines) without IdUrd (open symbols) and after incubation with $4 \mu \mathrm{M}$ of IdUrd (closed symbols). Control curve ip: open circles; control curve dp: open squares; idUrd ip: closed circles; idUrd dp: closed squares. Each point represents the mean value of three different experiments \pm SEM.

Fig. 6 depicts the survival curves of SW and V79 cell lines. The plating conditions of the V79 cells, i.e., exponentially growing cells plated prior to or after irradiation (ppi or pai, respectively), and plateau-phase cells, plated immediately or 6-24 h after irradiation (ip or dp, respectively), had no influence on the enhancement factor of the $\alpha$-value. It is demonstrated that the $\alpha$-value can be enhanced by a factor of 1.9 to 7.5 and that, in general, low $\alpha$-values are more enhanced than higher $\alpha$-values. The value of $\beta$ is less enhanced and its enhancement factor ranges from 0.7 to 2.4 .

The direct comparison between immediate and delayed plating of plateau-phase cells and between plateau-phase and exponentially growing cells shows significant quantitative differences. The data on the LQ parameters presented herein 
Table VI. Values of the linear parameter $\alpha$ and the enhancement factors from repair-proficient and repair-deficient MEF cells.

\begin{tabular}{|c|c|c|c|c|}
\hline MEF cells & $\begin{array}{c}\text { Treatment } \\
\text { with PARPi }\end{array}$ & $\alpha\left(\mathrm{Gy}^{-1}\right)$ & $\beta\left(\mathrm{Gy}^{-2}\right)$ & $\alpha-\mathrm{EF}$ \\
\hline $\operatorname{LigIV}^{+/+}, \operatorname{Rad} 54^{+/+}$ & No & $0.28 \pm 0.01$ & $\mathrm{Na}$ & \\
\hline $\mathrm{LigIV}^{+/+}, \operatorname{Rad} 54^{+/+}$ & Yes & $0.33 \pm 0.03$ & $\mathrm{Na}$ & 1.2 \\
\hline LigIV $^{-/-}, \operatorname{Rad} 54^{-/-}$ & No & $1.59 \pm 0.18$ & $\mathrm{Na}$ & \\
\hline $\mathrm{LigIV}^{-/-}, \operatorname{Rad} 54^{-/-}$ & Yes & $2.28 \pm 0.42$ & $\mathrm{Na}$ & 1.4 \\
\hline
\end{tabular}

The quadratic parameter $\beta$ could not be determined in these MEF cells. Na, not applicable; EF, enhancement factor. PARPi, PARP inhibitor.
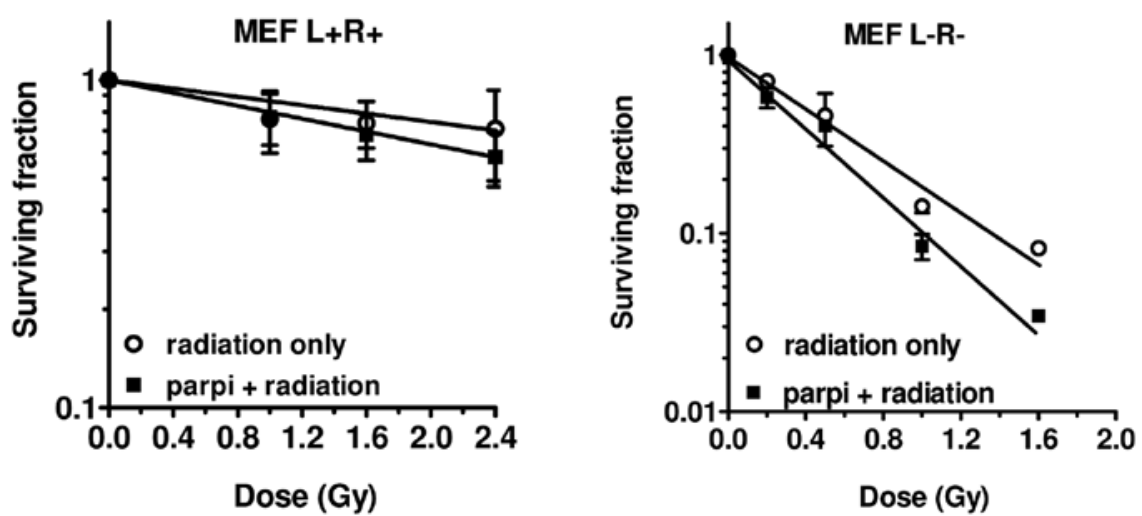

Figure 7. Radiation dose-survival curves of mouse embryonic fibroblasts (MEFs). Ligase IV- and RAD54-positive (LigIV ${ }^{+/+}$, Rad54 $^{+/+}$, left panel) and Ligase IVand RAD54-deficient (LigIV ${ }^{-/}$, Rad54 ${ }^{-/}$, right panel) MEFs. Open circles, radiation only curves; closed squares, radiation with PARP inhibitor (parpi). Cells were treated with $100 \mu \mathrm{M}$ of $\mathrm{Nu}-1025$ for $24 \mathrm{~h}$ prior to irradiation.

provide various new insights into the interpretation of radiosensitisation of dp plateau-phase cells. It is demonstrated that in dp HP-sensitised plateau-phase cells PLD is not abolished.

\section{PARP1 inhibitors}

The effect of inhibition of poly(ADP-ribose) polymerase-1 (PARP1) by olaparib on the LQ parameters was examined in mouse embryonic fibroblasts (MEFs). PARP1 is an enzyme which is involved in the repair of DNA SSBs. The DNA SSBs induced by ionizing radiation are mostly repaired by the base excision repair (BER) system, whereas the DNA DSBs are repaired by NHEJ or by HR. Inhibiting PARP1 activity reduces the repair of SSBs (95). Apart from its role in BER, PARP1 is further involved in a number of nuclear processes, such as DNA replication, transcription, DSB repair, apoptosis and genome stability (95-97). It was recently hypothesised that cells deficient in BRCA2 or BRCA1 are particularly sensitive to PARP1 inhibition $(27,96)$. SSBs are induced during DNA replication. In the absence of PARP1, these SSBs transform into DSBs. These DSBs are repaired with HR. Therefore, cells deficient in HR (e.g., BRCA1 or BRCA2 tumours) may be sensitive to PARP1 inhibitors. Since PARP1 is involved in numerous DNA repair processes, PARP1 inhibitors may function effectively as radiosensitisers (97). As can be observed in Fig. 7, we achieved a modest sensitisation effect by the PARP1 inhibitor NU-1025 in the MEF cell lines. The increase of the $\alpha$-value in the repair-deficient cell line was greater than in the repair-proficient cell line, 1.4 vs. 1.2, respectively (Table VI). The radiation dose-survival curves of these MEF cells did not exhibit a shoulder and therefore the quadratic parameter $\beta$ could not be determined.

\section{Discussion}

Radiosensitisation by a variety of chemotherapeutic agents is in most cases reflected by an increase of the linear or $\alpha$ component of the LQ model, which corresponds to an enhanced direct PLD at low radiation doses $(1,4-7,98,99)$. The $\beta$ component, which presumably depends on the interaction of repairable SLD, is affected by HT treatment. Furthermore, it appears that radiosensitisation is more pronounced in radioresistant than in radiosensitive cell lines. In addition, it can be concluded that the extent of radiosensitisation also depends on cell cycle stage (plateau or exponentially growing phase) and post-treatment plating conditions.

Hyperthermia. Hyperthermia (HT) is a very potent radiosensitiser, already effective at mild temperatures. HT for $1 \mathrm{~h}$ at $41^{\circ} \mathrm{C}$ without radiation exerted only a slight cytotoxic effect in both heat-sensitive and heat-resistant cell lines. This is in agreement with the general idea of cell kill induction at temperatures $\geq 42^{\circ} \mathrm{C}$ for $1 \mathrm{~h}$ or more (23). $\mathrm{HT}$ at $43^{\circ} \mathrm{C}$ for $1 \mathrm{~h}$ did not have a significant cytotoxic effect in heat-resistant SW-1573 cells. Radiosensitisation by $\mathrm{HT}$ at $41^{\circ} \mathrm{C}$ was observed in $\mathrm{SiHa}$ and RKO, but not in SW-1573 cells. The ability of mild HT 
$\left(40-42^{\circ} \mathrm{C}\right)$ to increase radiosensitivity of human tumour cells has been shown to be cell line-dependent $(8,26,100-105)$. In a study by Xu et al, pre-treatment of cells at $41.1^{\circ} \mathrm{C}$ for $1 \mathrm{~h}$ did not induce radiosensitisation, whereas treatment for $2 \mathrm{~h}$ or more resulted in radiosensitisation in the HT-resistant but not in the HT-sensitive cell line (106). However, simultaneous treatment of the sensitive cell line with $1-\mathrm{h} 41.1^{\circ} \mathrm{C}$ HT combined with irradiation increased cellular radiosensitivity (107). In vivo radiosensitisation by mild HT is usually attributed to reoxygenation of tumours by an increase in blood flow (108-110). We recently discovered that the BRCA2 protein is transiently inhibited by mild HT (27). Translocation of the Mre11 DSB repair protein from the nucleus to the cytoplasm has also been implicated $(106,111)$. However, disappearance of Mre11 protein foci at the sites of irradiation-induced DNA DSBs was not observed by pre-incubation of cells at $41^{\circ} \mathrm{C}(24,27)$. A role for mitotic catastrophe, occurring as a result of G2/M checkpoint abrogation, has also been suggested (112). It has been demonstrated that radiosensitisation by $\mathrm{HT}$ at $41-43^{\circ} \mathrm{C}$ correlates with an increased number of chromosomal fragments, but not of colour junctions, $24 \mathrm{~h}$ after treatment, compared to radiation alone (101). HT at clinically reachable temperatures mainly enhances the quadratic parameter, $\beta$, which represents the frequency of induction-repairable SLD. The fact that HT breaks down the repair protein BRCA2 and in this way influences DNA DSB repair correlates well with the effect on the repairable factor $\beta$.

Cisplatin. Cisplatin causes radiosensitisation as measured by clonogenic survival, but only after allowing a PLDR time of $24 \mathrm{~h}$. These results are in agreement with those of Wilkins et al (113), who investigated the effect of cisplatin and radiation on PLDR in confluent cultures of two different brain tumour cell lines (113). Wilkins et al did not observe radiosensitisation by cisplatin in ip cells, whereas a cisplatin-induced radiosensitisation was observed in dp cells $8 \mathrm{~h}$ following irradiation (114). Their results indicate that the radiosensitising effect of cisplatin is caused by the inhibition of post-irradiation recovery. The strongest inhibition of PLDR was achieved when cisplatin was administered shortly before or after irradiation $(113,114)$. In our experiments, cells were irradiated with cisplatin present in the medium.

Results from studies using exponentially growing cell cultures vary from a cisplatin-induced radiosensitisation (31-33,115), to a merely additive effect $(29,31,116-118)$. The effect of cisplatin treatment on radiosensitivity may depend on the cell type used. Loprevite et al (31) observed synergism in a squamous lung carcinoma cell line when exposed to cisplatin, whereas an adenocarcinoma of the lung was not sensitised by cisplatin (31). Even cell lines derived from a single biopsy can differ in their response to combined treatment with cisplatin and irradiation (116).

Although dependence on cell cycle phase $(119,120)$, cisplatin incubation time and sequence of treatment modalities have been implicated $(29,119,120)$, there is currently no consensus to account for the varying response of cells to cisplatin and irradiation.

The mechanism of cisplatin-induced radiosensitisation may be due to the inhibition of the DNA repair NHEJ and HR pathways $(38,43)$. The Ku protein complex, which plays an important role in NHEJ, was demonstrated to show a reduced ability to translocate on DNA containing cisplatin-DNA adducts compared with undamaged DNA. This resulted in a decreased interaction between $\mathrm{Ku}$ and DNA-dependent protein kinase catalytic subunit (DNA-PKcs) (121). However, the biochemical processes that cisplatin undergoes in the cell are complex and its intracellular fate may be linked to copper transport (122). Therefore, other processes, such as the formation of peroxy complexes inside the cell, may be involved in cisplatin-induced radiosensitisation (123). Bergs et al (34) demonstrated an increase in the induction of apoptosis $24 \mathrm{~h}$ after combined treatment as compared to radiation or cisplatin alone. This was confirmed by several other studies $(124,125)$. These apoptotic effects observed by Bergs et al correlated with clonogenic survival (34). Fujita et al (126) also observed an inhibitory effect of the combination of cisplatin and radiation on the survival of lung tumour cells and ascribed this effect to the induction of tumour cell apoptosis (126).

In conclusion, the radiosensitising effect of cisplatin on cell survival was observed in confluent cultures when cells were replated after a 24-hour incubation period during which PLDR was allowed to occur. By contrast, cisplatin did not induce a significant radiosensitisation after immediate plating.

Gemcitabine. A number of previous studies have demonstrated that gemcitabine is a potent sensitiser to ionizing radiation $(49,55,127)$. Among other proposed mechanisms of action, the effect of gemcitabine on cell cycle distribution may be the most important $(55,57)$. In our study, the gemcitabine-sensitive cell lines SWp and A2780 were sensitised to irradiation following administration of cytotoxic gemcitabine treatments. The radiosensitisation was accompanied by a clear arrest of cells in early S phase, which has been argued to be vital for gemcitabine-induced radiosensitisation (54). Both cell lines showed an increase in the $\alpha$-value, indicating the efficacy of gemcitabine-induced radiosensitisation in the clinically relevant dose range. The gemcitabine-resistant cells were also sensitised, although with only much higher gemcitabine doses. In the resistant AG6000 ovarian carcinoma cell line, this was demonstrated by an increase in the $\alpha$-value. By contrast, in the gemcitabine-resistant lung tumour cell line an increase in the $\beta$-value was observed, while the $\alpha$-value was not affected. In both gemcitabine-resistant cell lines the sensitivity to ionizing radiation alone was not altered. It is reported that gemcitabine-resistant tumours are cross-resistant to related drugs like Ara-C $(128,129)$. In the AG6000 and SWg gemcitabine-resistant cell lines, this was indeed the case (64). Moreover, the AG6000 cells were more resistant to cisplatin and taxoids as well (62). However, no altered sensitivity was observed in SWg cells for cisplatin, paclitaxel, methotrexate (MTX) and 5-fluorouracil (5-FU), while AG6000 cells were 2.5-fold more sensitive to MTX (62). These findings indicate that patients previously treated with gemcitabine may still benefit from radiotherapy combined with cisplatin or paclitaxel.

Temozolomide. The potential of TMZ to enhance the radiation response in long-term primary GBM cell lines has been clearly demonstrated (10) and therewith, the rationale for the clinical use of this drug concomitantly with radiotherapy. A distinct increase of the $\alpha$ parameter is shown following treat- 
ment with TMZ. The three MGMT promoter methylated cell lines discussed above responded differently to the combination treatment, even though they were treated at similar TMZ sensitivity levels. The combined effect of TMZ and radiation was found to be synergistic and is at least additive.

Halogenated pyrimidines. Radiosensitisation by halogenated pyrimidines (HPs) is mainly due to an increase in the linear parameter $\alpha$. The quadratic parameter $\beta$ is rarely influenced. Different radiosensitisation mechanisms induced by HPs have been described. Wang et al (130) suggested that increased DNA damage was the major component of radiosensitisation in exponentially growing cells, while in plateau-phase cells, radiosensitisation occurred through inhibited repair and/or enhanced fixation of PLD $(6,90)$. The increase of the $\alpha$-values for exponentially growing cells, as presented in our study, indicates an increase in the number of directly lethal events due to the HPs. This is in agreement with the observations of Webb et al (131) and Jones et al (94), which suggested that an important mechanism of radiosensitisation involves an increase of effective DNA DSBs $(87,89,130)$. Miller et al $(92,93)$ suggested that radiation-induced damage in cells which have HPs incorporated into the DNA after low-LET radiation resembles the damage produced by high-LET radiation. In plateau-phase cells plated immediately after irradiation, the increase of $\alpha$ might be due to the same mechanism as involved in exponentially growing cells. In these cells an increase of $\beta$ was also observed, indicating that accumulation of SLD was a major contributor (2). Due to the immediate plating after irradiation this SLD may be fixated.

The most significant increases in the $\alpha$ value were observed in dp plateau-phase cells. This radiosensitisation may be interpreted as an enhanced fixation of PLD due to immediate DNA damage and/or to damaged DNA repair function in these cells, expressed during the interval before delayed plating. The value of $\beta$ in these cells returned to values found in cells not containing HPs. This demonstrates that SLD was repaired in HP-containing plateau-phase cells.

PARP1 inhibitors. Since PARP1 has been implicated in several DNA repair processes, PARP1 inhibitors may be good radiosensitisers. Several studies have already demonstrated the radiosensitising effect of PARP1 inhibitors $(27,95,132)$. Löser et al (97) concluded that the effects of PARP1 inhibitors are more pronounced on rapidly dividing and/or DNA repair-deficient cells (95). In our study, at the time of treatment most of the cells in culture were accumulated in G1 phase. Therefore, radiosensitisation effects were modest. However, the increase in the $\alpha$-value in repair-deficient cells was more pronounced following PARP1 inhibition than in repair-proficient cells.

\section{Conclusion}

The increase in the $\alpha$ parameter by the various radiosensitising agents yields promising perspective for clinical practice. The radiation tolerance dose is generally expressed quantitatively in terms of the biologically effective dose (BED), as defined by the LQ model. BED takes total dose, dose per fraction, dose rate and overall treatment time into account. By definition, $\mathrm{BED}$ is the total dose required to obtain an equal biological effect $\mathrm{E}$ (isoeffect) for a certain endpoint, e.g., few log cell kill (e.g., $10^{-2}$ cell survival), a normal tissue effect (e.g., $1 \%$ complication rate) or tumour response (e.g., tumour cure rate of $50 \%$ ) when applying an infinite number $(\infty)$ of tiny dose fractions $(\sim 0)$. At this point, the $\alpha$ parameter is inversely proportional to BED [BED $=\mathrm{E} / \alpha$; (133)]. With increasing $\alpha$, $\mathrm{BED}$ is decreasing, resulting in a lower radiation tolerance dose for a certain isoeffect.

The radiosensitising effect of HT on the LQ parameters seems to be temperature-dependent. HT for $1 \mathrm{~h}$ at $41^{\circ} \mathrm{C}$ increases the $\beta$-value while $\mathrm{HT}$ for $1 \mathrm{~h}$ at $43^{\circ} \mathrm{C}$ increases both the $\alpha$ - and $\beta$-values. Increase of the $\beta$-value consequently lowers the $\alpha / \beta$ ratio, which makes the tumour more sensitive to higher fraction doses. The effects of HT on BED remain to be elucidated.

Radiosensitising agents that selectively sensitise tumour cells and not normal tissue cells will be of therapeutic benefit. This is due to the increase of the $\alpha$ parameter of tumour cells only and, as a consequence, the decrease in tumour response dose proportionally to the relative increase in $\alpha$. This effect could be further exploited using smaller sized fractions in external beam radiotherapy or by lowering the dose rate in brachytherapy. With lower fraction size or lower dose rate, normal tissue cells with low $\alpha / \beta$ ratios will tolerate a higher total dose. Tumour tissues with high $\alpha / \beta$ ratios will not exhibit an increased sparing effect, since an increase in $\alpha$ by a radiosensitising agent will further increase the $\alpha / \beta$ ratio, resulting in even less sensitivity to a modification in fraction size. However, since an increase in the number of fractions or a lower dose rate might increase the overall treatment time, tumour cell repopulation rate should be taken into account.

\section{Acknowledgements}

We thank Jan Sijbrands for his technical support. The authors are thankful for financial support from several foundations. The Maurits and Anna de Kock and the Nijbakker Morra foundations are acknowledged for sponsoring laboratory equipment. The Dutch Cancer Foundation (grant nos. UVA 2006-3484, UVA 2008-4019 and UVA 2012-5540) and the Stichting Vanderes are acknowledged for financing personnel support.

\section{References}

1. Barendsen GW: Dose fractionation, dose rate and iso-effect relationships for normal tissue responses. Int J Radiat Oncol Biol Phys 8: 1981-1997, 1982.

2. Barendsen GW: Mechanisms of cell reproductive death and shapes of radiation dose-survival curves of mammalian cells. Int J Radiat Biol 57: 885-896, 1990.

3. Barendsen GW: The relationships between RBE and LET for different types of lethal damage in mammalian cells: biophysical and molecular mechanisms. Radiat Res 139: 257-270, 1994.

4. Barendsen GW: Parameters of linear-quadratic radiation doseeffect relationships: dependence on LET and mechanisms of reproductive cell death. Int J Radiat Biol 71: 649-655, 1997.

5. Barendsen GW, van Bree C and Franken NAP: Importance of cell proliferative state and potentially lethal damage repair on radiation effectiveness: Implications for combined tumor treatments (Review). Int J Oncol 19: 257-256, 2001.

6. Franken NAP, van Bree C, Kipp JB and Barendsen GW: Modification of potentially lethal damage in irradiated Chinese hamster V79 cells after incorporation of halogenated pyrimidines. Int J Radiat Biol 72: 101-109, 1997. 
7. Franken NAP, Ten Cate R, van Bree C and Haveman J: Induction of the early response protein EGR-1 in human tumour cells after ionizing radiation is correlated with a reduction of repair of lethal lesions and an increase of repair of sublethal lesions. Int J Oncol 24: 1027-1031, 2004.

8. Franken NAP, van Bree C, Veltmaat MA, Ludwików G, Kipp JB and Barendsen GW: Increased chromosome exchange frequencies in iodo-deoxyuridine-sensitized human SW-1573 cells after $\gamma$-irradiation. Oncol Rep 6: 59-63, 1999.

9. Franken NAP, Rodermond HM, Stap J, Haveman J and van Bree C: Clonogenic assay of cells in vitro. Nature Protoc 1: 2315-2319, 2006

10. van Nifterik KA, van den Berg J, Stalpers LJA, Lafleur MV, Leenstra S, Slotman BJ, Hulsebos TJ and Sminia P: Differential radiosensitizing potential of temozolomide in MGMT promoter methylated glioblastoma multiforme cell lines. Int J Radiat Oncol Biol Phys 69: 1246-1253, 2007.

11. van Bree C, Franken NAP, Bakker PJ, Klomp-Tukker LJ, Barendsen GW and Kipp JB: Hyperthermia and incorporation of halogenated pyrimidines: radiosensitization in cultured rodent and human tumor cells. Int J Radiat Oncol Biol Phys 39: 489-496, 1997.

12. González González D, Van Dijk JD and Blank LE: Radiotherapy and hyperthermia. Eur J Cancer 31A: 1351-1355, 1995.

13. van der Zee J, González González D, van Rhoon GC van Dijk JD, van Putten WL and Hart AA: Comparison of radiotherapy alone with radiotherapy plus hyperthermia in locally advanced pelvic tumours: a prospective, randomised, multicentre trial. Dutch Deep Hyperthermia Group. Lancet 355: 1119-1125, 2000.

14. van der Zee J, Treurniet-Donker AD, The SK, Helle PA, Seldenrath JJ, Meerwaldt JH, Wijnmalen AJ, van de Berg AP, van Rhoon GC, Broekmeyer-Reurink MP, et al: Low dose reirradiation in combination with hyperthermia: a palliative treatment for patients with breast cancer recurring in previously irradiated areas. Int J Radiat Oncol Biol Phys 15: 1407-1413, 1988.

15. van der Zee J and González GD: The Dutch Deep Hyperthermia Trial: results in cervical cancer. Int J Hyperthermia 18: 1-12, 2002. Erratum in: Int J Hyperthermia 19: 213, 2003

16. Crezee J, Barendsen GW, Westermann AM, Hulshof MC, Haveman J, Stalpers LJ, Geijsen ED and Franken NAP: Quantification of the contribution of hyperthermia to results of cervical cancer trials: in regard to Plataniotis and Dale (Int J Radiat Oncol Biol Phys 73: 1538-1544, 2009). Int J Radiat Oncol Biol Phys 75: 634, 2009.

17. Dewey WC, Sapareto SA and Betten DA: Hyperthermic radiosensitization of synchronous Chinese hamster cells: relationship between lethality and chromosomal aberrations. Radiat Res 76: 48-59, 1978

18. Roti Roti JL: Introduction: radiosensitization by hyperthermia Int J Hyperthermia 20: 109-114, 2004.

19. Raaphorst GP, Feeley MM, Danjoux CE, DaSilva V and Gerig LH: Hyperthermia enhancement of radiation response and inhibition of recovery from radiation damage in human glioma cells. Int J Hyperthermia 7: 629-641, 1991.

20. Kampinga $\mathrm{HH}$ and Dikomey E: Hyperthermic radiosensitization: mode of action and clinical relevance. Int J Radiat Biol 77: 399-408, 2001

21. Hildebrandt B, Wust P, Ahlers O, Dieing A, Sreenivasa G, Kerner T, Felix R and Riess H: The cellular and molecular basis of hyperthermia. Crit Rev Oncol Hematol 43: 33-56, 2002.

22. Hall EJ and Giaccia AJ: Hyperthermia. In: Radiobiology for the Radiologist. Chapter 28. 6th edition. Lippincott Williams \& Wilkins, Philadelphia, PA, pp469-490, 2006.

23. Dewhirst MW, Vujaskovic Z, Jones E and Thrall D: Re-setting the biologic rationale for thermal therapy. Int J Hyperthermia 21: 779-790, 2005

24. Bergs JWJ: Hyperthermia, cisplatin and radiation trimodality treatment: In vitro studies on interaction mechanisms. PhD Thesis, University of Amsterdam, 2007.

25. Bergs JWJ, Haveman J, Ten Cate R, Medema JP, Franken NAP and van Bree $\mathrm{C}$ : Effect of $41^{\circ} \mathrm{C}$ and $43^{\circ} \mathrm{C}$ on cisplatin radiosensitization in two human carcinoma cell lines with different sensitivities for cisplatin. Oncol Rep 18: 219-226, 2007.

26. Bergs JWJ, Franken NAP, Haveman J, Geijsen ED, Crezee J and van Bree C: Hyperthermia, cisplatin and radiation trimodality treatment: a promising cancer treatment? A review from preclinical studies to clinical application. Int J Hyperthermia 23: 329-341, 2007.
27. Krawczyk PM, Eppink B, Essers J, Stap J, Rodermond H, Odijk H, Zelensky A, van Bree C, Stalpers LJ, Buist MR, Soullié T, Rens J, Verhagen HJ, O'Connor MJ, Franken NAP, Ten Hagen TL, Kanaar R and Aten JA: Mild hyperthermia inhibits homologous recombination, induces BRCA2 degradation, and sensitizes cancer cells to poly(ADP-ribose) polymerase-1 inhibition. Proc Natl Acad Sci USA 108: 9851-9856, 2011

28. Franken NAP, van Bree $\mathrm{C}$, Ten Cate $\mathrm{R}$, van Oven $\mathrm{CH}$ and Haveman J: Importance of TP53 and RB in the repair of potentially lethal damage and induction of color junctions after exposure to ionizing radiation. Radiat Res 158: 707-714, 2002.

29. Gorodetsky R, Levy-Agababa F, Mou X and Vexler AM Combination of cisplatin and radiation in cell culture: effect of duration of exposure to drug and timing of irradiation. Int J Cancer 75: 635-642, 1998

30. Dueñas-Gonzalez A, Cetina L, Mariscal I and de la Garza J: Modern management of locally advanced cervical carcinoma. Cancer Treat Rev 29: 389-399, 2003.

31. Loprevite M, Favoni RE, de Cupis A, Pirani P, Pietra G, Bruno S, Grossi F, Scolaro T and Ardizzoni A: Interaction between novel anticancer agents and radiation in non-small cell lung cancer cell lines. Lung Cancer 33: 27-39, 2001

32. Begg AC, van der Kolk PJ, Dewit L and Bartelink $H$ : Radiosensitization by cisplatin of RIF1 tumour cells in vitro. Int J Radiat Biol Relat Stud Phys Chem Med 50: 871-884, 1986.

33. Nakamoto S, Mitsuhashi N, Takahashi T, Sakurai H and Niibe H: An interaction of cisplatin and radiation in two rat yolk sac tumour cell lines with different radiosensitivities in vitro. Int J Radiat Biol 70: 747-753, 1996.

34. Bergs JWJ, Franken NAP, Ten Cate R, van Bree C and Haveman J: Effects of cisplatin and gamma-irradiation on cell survival, the induction of chromosomal aberrations and apoptosis in SW-1573 cells. Mutat Res 594: 148-154, 2006.

35. Fehlauer F, Barten-Van Rijbroek AD, Stalpers LJ, Leenstra S, Lindeman J, Tjahja I, Troost D, Wolbers JG, van der Valk P and Sminia P: Additive cytotoxic effect of cisplatin and X-irradiation on human glioma cell cultures derived from biopsy-tissue. J Cancer Res Clin Oncol 126: 711-716, 2000.

36. Rabik CA and Dolan ME: Molecular mechanisms of resistance and toxicity associated with platinating agents. Cancer Treat Rev 33: 9-23, 2007.

37. Crul M, van Waardenburg RC, Beijnen JH and Schellens JH: DNA-based drug interactions of cisplatin. Cancer Treat Rev 28: 291-303, 2002

38. Myint WK, Ng C and Raaphorst GP: Examining the nonhomologous repair process following cisplatin and radiation treatments. Int J Radiat Biol 78: 417-424, 2002

39. Lawrence TS, Blackstock AW and McGinn C: The mechanism of action of radiosensitization of conventional chemotherapeutic agents. Semin Radiat Oncol 13: 13-21, 2003.

40. Haveman J, Castro Kreder N, Rodermond HM, van Bree C, Franken NAP, Stalpers LJ, Zdzienicka MZ and Peters GJ: Cellular response of X-ray sensitive hamster mutant cell lines to gemcitabine, cisplatin and 5-fluorouracil. Oncol Rep 12: 187-192, 2004.

41. De Silva IU., McHugh PJ, Clingen PH and Hartley JA: Defects in interstrand cross-link uncoupling do not account for the extreme sensitivity of ERCC1 and XPF cells to cisplatin. Nucleic Acids Res 30: 3848-3856, 2002.

42. Dronkert ML and Kanaar R: Repair of DNA interstrand cross-links. Mutat Res 486: 217-247, 2001.

43. Dolling JA, Boreham DR, Brown DL, Raaphorst GP and Mitchel RE: Cisplatin-modification of DNA repair and ionizing radiation lethality in yeast, Saccharomyces cerevisiae. Mutat Res 433: 127-136, 1999 .

44. Fossella FV, Lipmann SM, Shin DM, Tarassoff $P$, Calayag-Jung M, Perez-Soler R, Lee JS, Murphy WK, Glisson B, Rivera E and Hong WK: Maximum-tolerated dose defined for single-agent gemcitabine: a phase I dose-escalation study in chemotherapy-naive patients with advanced non-small-cell lung cancer. J Clin Oncol 15: 310-316, 1997.

45. Manegold C, Zatloukal P, Krejcy K and Blatter J: Gemcitabine in non-small lung cancer (NSCLC). Invest New Drugs 18: 29-42, 2000.

46. Shewach DS and Lawrence TS: Gemcitabine and radiosensitization in human tumor cells. Invest New Drugs 14: 257-263, 1996.

47. Castro Kreder N, van Bree C, Franken NAP and Havenman J: Effects of gemcitabine on cell survival and chromosome aberrations after pulsed low dose-rate irradiation. J Radiat Res 45: $111-118,2004$ 
48. Heinemann V, Xu YZ, Chubb S, Sen A, Hertel LW, Grindey GB and Plunkett W: Cellular elimination of $2^{\prime}, 2^{\prime}$-difluorodeoxycytidine 5'-triphosphate: a mechanism of self-potentiation. Cancer Res 52: 533-539, 1992

49. Shewach DS, Hahn TM, Chang E, Hertel LW and Lawrence TS Metabolism of 2',2'-difluoro-2'-deoxycytidine and radiation sensitization of human colon carcinoma cells. Cancer Res 54 3218-3223, 1994.

50. Plunkett W, Huang P and Gandhi V: Preclinical characteristics of gemcitabine. Anticancer Drugs 6 (Suppl 6): 7-13, 1995.

51. Auer H, Oehler R, Lindner R, Kowalski H, Sliutz G, Orel L, Kucera E, Simon MM and Glössl J: Characterisation of genotoxic properties of 2',2'-difluorodeoxycytidine. Mutat Res 393: 165-173, 1997.

52. Rockwell S and Grindey GB: Effect of 2',2'-difluorodeoxycytidine on the viability and radiosensitivity of EMT6 cells in vitro. Oncol Res 4: 151-155, 1992.

53. Shewach DS and Lawrence TS: Radiosensitization of human solid tumor cell lines with gemcitabine. Semin Oncol 23 (Suppl 10): 65-71, 1996

54. Latz D, Fleckenstein K, Eble M, Blatter J, Wannenmacher M and Weber KJ: Radiosensitizing potential of gemcitabine (2',2'-difluoro-2'-deoxycytidine) within the cell cycle in vitro. Int J Radiat Oncol Biol Phys 41: 875-882, 1998

55. Gregoire V, Hittelman WN, Rosier JF and Milas L: Chemoradiotherapy: Radiosensitizing nucleoside analogues (Review). Oncol Rep 6: 949-957, 1999.

56. Milas L, Fujii T, Hunter N, Elshaikh M, Mason K, Plunkett W, Ang KK and Hittelman W: Enhancement of tumor radioresponse in vivo by gemcitabine. Cancer Res 59: 107-114, 1999.

57. van Putten JWG, Groen HJM, Smid K, Peters GJ and Kampinga HH: End-joining deficiency and radiosensitization induced by gemcitabine. Cancer Res 61: 1585-1591,2001.

58. Wachters FM, van Putten JWG, Maring JG, Zdzienicka MZ, Groen $\mathrm{HJ}$ and Kampinga $\mathrm{HH}$ : Selective targeting of homologous DNA recombination repair by gemcitabine. Int $\mathbf{J}$ Radiat Oncol Biol Phys 57: 553-562, 2002

59. Castro Kreder N, van Bree C, Franken NAP and Haveman J: Colour junctions as predictors of radiosensitivity: $\mathrm{X}$-irradiation combined with gemcitabine in a lung carcinoma cell line. J Cancer Res Clin Oncol 129: 597-603, 2003.

60. Scalliet P, Goor C, Galdermans J, et al: Gemzar (gemcitabine) with thoracic radiotherapy - a phase II pilot study in chemo-naive patients with advanced non-small-cell lung cancer (NSCLC) (Abstract). Proc ASCO 17: 499a, 1998.

61. Blackstock AW, Lesser GJ, Fletcher-Steede J, Case LD Tucker RW, Russo SM, White DR and Miller A: Phase I study of twice-weekly gemcitabine and concurrent thoracic radiation for patients with locally advanced non-small cell lung cancer. Int J Radiat Oncol Biol Phys 51: 1281-1289, 2001.

62. Bergman AM, Giaccone G, van Moorsel CJ, Mauritz R, Noordhuis P, Pinedo HM and Peters GJ: Cross-resistance in the 2',2'-difluorodeoxycytidine (gemcitabine)-resistant human ovarian cancer cell line AG6000 to standard and investigational drugs. Eur J Cancer 36: 1974-1983, 2000.

63. Bergman AM, Pinedo HM, Jongsma AP, Brouwer M, Ruiz van Haperen VW, Veerman G, Leyva A, Eriksson S and Peters GJ: Decreased resistance to gemcitabine (2',2'-difluorodeoxycitidine) of cytosine arabinoside-resistant myeloblastic murine and rat leukemia cell lines: role of altered activity and substrate specificity of deoxycytidine kinase. Biochem Pharmacol 57: 397-406, 1999.

64. van Bree C, Castro Kreder N, Loves WJ, Franken NAP, Peters GJ and Haveman J: Sensitivity to ionizing radiation and chemotherapeutic agents in gemcitabine-resistant human tumor cell lines. Int J Radiat Oncol Biol Phys 54: 237-244, 2002.

65. Stupp R, Mason WP, van den Bent MJ, Weller M, Fisher B Taphoorn MJ, Belanger K, Brandes AA, Marosi C, Bogdahn U, Curschmann J, Janzer RC, Ludwin SK, Gorlia T, Allgeier A, Lacombe D, Cairncross JG, Eisenhauer E and Mirimanoff RO; European Organisation for Research and Treatment of Cancer Brain Tumor and Radiotherapy Groups; National Cancer Institute of Canada Clinical Trials Group: Radiotherapy plus concomitant and adjuvant temozolomide for glioblastoma. N Engl J Med 352: 987-996, 2005

66. Stupp R, Hegi ME, Mason WP, van den Bent MJ, Taphoorn MJ, Janzer RC, et al: Effects of radiotherapy with concomitant and adjuvant temozolomide versus radiotherapy alone on survival in glioblastoma in a randomised phase III study: 5-year analysis of the EORTC-NCIC trial. Lancet Oncol 10: 459-466, 2009.
67. Hegi ME, Diserens AC, Godard S, Dietrich PY, Regli L, Ostermann S, Otten P, Van Melle G, de Tribolet N and Stupp R: Clinical trial substantiates the predictive value of O-6-methylguanine-DNA methyltransferase promoter methylation in glioblastoma patients treated with temozolomide. Clin Cancer Res 10: 1871-1874, 2004.

68. Hegi ME, Diserens AC, Gorlia T, Hamou MF, de Tribolet N, Weller M, Kros JM, Hainfellner JA, Mason W, Mariani L, Bromberg JE, Hau P, Mirimanoff RO, Cairncross JG, Janzer RC and Stupp R: MGMT gene silencing and benefit from temozolomide in glioblastoma. N Engl J Med 352: 997-1003, 2005.

69. Brennand J, Margison GP: Reduction of the toxicity and mutagenicity of alkylating agents in mammalian cells harboring the Escherichia coli alkyltransferase gene. Proc Natl Acad Sci USA 83: 6292-6296, 1986.

70. Wedge SR, Porteus JK, May BL and Newlands ES: Potentiation of temozolomide and BCNU cytotoxicity by $\mathrm{O}(6)$-benzylguanine: a comparative study in vitro. Br J Cancer 73: 482-490, 1996.

71. Karran P, Macpherson P, Ceccotti S, Ceccotti S, Dogliotti E, Griffin $\mathrm{S}$ and Bignami $\mathrm{M}$ : $\mathrm{O}^{6}$-methylguanine residues elicit DNA repair synthesis by human cell extracts. J Biol Chem 268: 15878-15886, 1993.

72. Ochs K and Kaina B: Apoptosis induced by DNA damage $\mathrm{O}^{6}$-methylguanine is $\mathrm{Bcl}-2$ and caspase-9/3 regulated and Fas/caspase-8 independent. Cancer Res 60: 5815-5824, 2000.

73. Gerson SL: MGMT: its role in cancer aetiology and cancer therapeutics. Nat Rev Cancer 4: 296-307, 2004

74. Hotta T, Saito Y,Fujita H,Mikami T, Kurisu K, Kiya K, Uozumi T, Isowa $\mathrm{G}$, Ishizaki $\mathrm{K}$ and Ikenaga $\mathrm{M}$ : $\mathrm{O}^{6}$-alkylguanine-DNA alkyltransferase activity of human malignant glioma and its clinical implications. J Neurooncol 21: 135-140, 1994.

75. Qian XC and Brent TP: Methylation hot spots in the 5' flanking region denote silencing of the $\mathrm{O}^{6}$-methylguanine-DNA methyltransferase gene. Cancer Res 57: 3672-3677, 1997.

76. Watts GS, Pieper RO, Costello JF, Peng YM, Dalton WS and Futscher BW: Methylation of discrete regions of the $\mathrm{O}^{6}$-methylguanine DNA methyltransferase (MGMT) $\mathrm{CpG}$ island is associated with heterochromatinization of the MGMT transcription start site and silencing of the gene. Mol Cell Biol 17: 5612-5619, 1997

77. Paz MF, Yaya-Tur R, Rojas-Marcos I, Reynes G, Pollan M, Aguirre-Cruz L, García-Lopez JL, Piquer J, Safont MJ, Balaña C, Sanchez-Cespedes M, García-Villanueva M, Arribas L and Esteller M: CpG island hypermethylation of the DNA repair enzyme methyltransferase predicts response to temozolomide in primary gliomas. Clin Cancer Res 10: 4933-4938, 2004.

78. Donson AM, Addo-Yobo SO, Handler MH, Gore L and Foreman NK: MGMT promoter methylation correlates with survival benefit and sensitivity to temozolomide in pediatric glioblastoma. Pediatr Blood Cancer 48: 403-407, 2007.

79. Chalmers AJ, Ruff EM, Martindale C, Lovegrove N and Short SC: Cytotoxic effects of temozolomide and radiation are additive- and schedule-dependent. Int J Radiat Oncol Biol Phys 75: 1511-1519, 2009

80. Esteller M, Garcia-Foncillas J, Andion E, Goodman SN, Hidalgo OF, Vanaclocha V, Baylin SB and Herman JG: Inactivation of the DNA-repair gene MGMT and the clinical response of gliomas to alkylating agents. N Engl J Med 343: $1350-1354,2000$

81. Chakravarti A, Erkkinen MG, Nestler U, Stupp R, Mehta M, Aldape K, Gilbert MR, Black PM and Loeffler JS: Temozolomide-mediated radiation enhancement in glioblastoma: a report on underlying mechanisms. Clin Cancer Res 12: 4738-4746, 2006

82. van Rijn J, Heimans JJ, van den Berg J, van der Valk P and Slotman BJ: Survival of human glioma cells treated with various combinations of temozolomide and X-rays. Int J Radiat Oncol Biol Phys 47: 779-784, 2000.

83. Wedge SR, Porteous JK, Glaser MG, Marcus K and Newlands ES: In vitro evaluation of temozolomide combined with $\mathrm{X}$-irradiation. Anticancer Drugs 8: 92-97, 1997.

84. van Nifterik KA, van den Berg J, van der Meide WF, Ameziane N, Wedekind LE, Steenbergen RD, Leenstra S, Lafleur MV, Slotman BJ, Stalpers LJ and Sminia P: Absence of the MGMT protein as well as methylation of the MGMT promoter predict the sensitivity for temozolomide. Br J Cancer 103: 29-35, 2010.

85. van Nifterik KA, van den Berg J, Slotman BJ, Lafleur MV, Sminia P, Stalpers LJ: Valproic acid sensitizes human glioma cells for temozolomide and $\gamma$-radiation. J Neurooncol 107: 61-67, 2012. 
86. Franken NAP, van Bree C, Streefkerk J, Kuper I, Rodermond H, Kipp JB and Barendsen GW: Radiosensitization by iodo-deoxyuridine in cultured SW-1573 human lung tumor cells: Effects on $\alpha$ and $\beta$ of the linear-quadratic model. Oncol Rep 4: 1073-1076, 1997.

87.Franken NAP, Ruurs P, Ludwików G, van Bree C, Kipp JB, Darroudi F and Barendsen GW: Correlation between cell reproductive death and chromosome aberrations assessed by FISH for low and high doses of radiation and sensitization by iododeoxyuridine in human SW-1573 cells. Int J Radiat Biol 75: 293-299, 1999.

88. Iliakis G, Kurtzman S, Pantelias G and Okayasu R: Mechanism of radiosensitisation by halogenated pyrimidines: effect of BrdU on radiation induction of DNA and chromosome damage and its correlation with cell killing. Radiat Res 119: 286-304 1989.

89. Iliakis G, Wang Y, Pantelias GE and Metzger L: Mechanism of radiosensitisation of halogenated pyrimidines: effect of BrdU on repair of DNA breaks, interphase chromatin breaks and potentially lethal damage in plateau-phase $\mathrm{CHO}$ cells. Radiat Res 129: 202-211, 1992.

90.Iliakis G, Wright E and Ngo FQ: Possible importance of PLD repair in the modulation of BrdUrd and IdUrd-mediated radiosensitisation in plateau-phase $\mathrm{C} 3 \mathrm{H} 10 \mathrm{~T} 1 / 2$ mouse embryo cells. Int J Radiat Biol Relat Stud Phys Chem Med 51: 541-548, 1987.

91. Iliakis G, Pantelias G and Kurtzman S: Mechanism of radiosensitisation by halogenated pyrimidines: effect of BrdU on cell killing and interphase chromosome breakage in radiation-sensitive cells Radiat Res 25: 56-64, 1991.

92. Miller EM, Fowler JF and Kinsella TJ: Linear-quadratic analysis of radiosensitisation by halogenated pyrimidines. I. Radiosensitisation of human colon cancer cells by iododeoxyuridine. Radiat Res 131: 81-89, 1992.

93. Miller EM, Fowler JF and Kinsella TJ: Linear-quadratic analysis of radiosensitisation by halogenated pyrimidines. II. Radiosensitisation of human colon cancer cells by bromodeoxyuridine. Radiat Res 131: 90-97, 1992.

94. Jones GD, Ward JF, Limoli CL, Moyer DJ and Aguilera JA: Mechanisms of radiosensitization in iododeoxyuridinesubstituted cells. Int J Radiat Biol 67: 647-653, 1995.

95. Bouchard VJ, Rouleau M and Poirier GG: PARP-1, a determinant of cell survival in response to DNA damage. Exp Hematol 31: 446-454, 2003

96. Rouleau M, Patel A, Hendzel MJ, Kaufmann SH and Poirier GG: PARP inhibition: PARP1 and beyond. Nat Rev Cancer 10: 293-301, 2010.

97.Löser DA, Shibata A, Shibata AK, Woodbine LJ, Jeggo PA and Chalmers AJ: Sensitization to radiation and alkylating agents by inhibitors of poly(ADP-ribose) polymerase is enhanced in cells deficient in DNA double-strand break repair. Mol Cancer Ther 9: 1775-1787, 2010 .

98. Cate RT, Krawczyk P, Stap J, Aten JA and Franken NAP. Radiosensitizing effect of the histone acetyltransferase inhibitor anacardic acid on various mammalian cell lines. Oncol Lett 1 : 765-769, 2010.

99. Rodermond HM, Ten Cate R, Haveman J, van Kuilenburg A, Medema JP, van Bree C and Franken NAP: Cyclopentenylcytosine does not enhance cisplatin-induced radiosensitization in human lung tumour cells. Oncol Lett 1: 537-540, 2010.

100.Ryu S, Brown SL, Kim SH, Khil MS and Kim JH: Preferential radiosensitization of human prostatic carcinoma cells by mild hyperthermia. Int J Radiat Oncol Biol Phys 34: 133-138, 1996.

101. Bergs JWJ, Ten Cate R, Haveman J, Medema JP, Franken NAP and van Bree C: Chromosome fragments have the potential to predict hyperthermia-induced radio-sensitization in two different human tumor cell lines. J Radiat Res 49: 465-472, 2008.

102.van Bree C, Savonije JH, Franken NAP, Haveman J and Bakker PJ: The effect of p53-function on the sensitivity to paclitaxel with or without hyperthermia in human colorectal carcinoma cells. Int J Oncol 16: 739-744, 2000.

103.van Bree C, van der Maat B, Ceha HM, Franken NAP, Haveman $\mathbf{J}$ and Bakker PJ: Inactivation of p53 and of pRb protects human colorectal carcinoma cells against hyperthermia-induced cytotoxicity and apoptosis. J Cancer Res Clin Oncol 125: 549-555, 1992.
104.Larsson $\mathrm{C}$ and $\mathrm{Ng} \mathrm{CE}$ : $\mathrm{p} 21^{+/+}\left(\mathrm{CDKN} 1 \mathrm{~A}^{+/+}\right)$and $\mathrm{p} 21^{-/}$ $\left(\mathrm{CDKN} 1 \mathrm{~A}^{-/}\right)$human colorectal carcinoma cells display equivalent amounts of thermal radiosensitization. Radiat Res 160: 205-209, 2003.

105. Murthy AK, Harris JR and Belli JA: Hyperthermia and radiation response of plateau phase cells. Potentiation and radiation damage repair. Radiat Res 70: 241-247, 1977.

106. Xu M, Myerson RJ, Xia Y, Whitehead T, Moros EG, Straube WL and Roti Roti JL: The effects of 41 degrees $C$ hyperthermia on the DNA repair protein, MRE11, correlate with radiosensitization in four human tumor cell lines. Int J Hyperthermia 23: 343-351, 2007

107. Xu M, Wright WD, Higashikubo R, Wang LL and Roti Roti JL: Thermal radiosensitization of human tumour cell lines with different sensitivities to 41.1 degrees C. Int J Hyperthermia 15: 279-290, 1999

108. VujaskovicZand Song CW: Physiological mechanisms underlying heat-induced radiosensitization. Int J Hyperthermia 20: 163-174, 2004

109. Oleson JR: Eugene Robertson Special Lecture.Hyperthermia from the clinic to the laboratory: a hypothesis. Int J Hyperthermia 11: 315-322, 1995.

110. Song CW, Shakil A, Osborn JL and Iwata K: Tumour oxygenation is increased by hyperthermia at mild temperatures. Int J Hyperthermia 12: 367-373, 1996.

111. Xu M, Myerson RJ, Straube WL, Moros EG, Lagroye I, Wang LL, Lee JT and Roti Roti JL: Radiosensitization of heat resistant human tumour cells by 1 hour at 41.1 degrees $C$ and its effect on DNA repair. Int J Hyperthermia 18: 385-403, 2002.

112. Mackey MA and Ianzini F: Enhancement of radiation-induced mitotic catastrophe by moderate hyperthermia. Int J Radiat Biol 76: 273-280, 2000

113. Wilkins DE, Ng CE and Raaphorst GP: Cisplatin and low dose rate irradiation in cisplatin resistant and sensitive human glioma cells. Int J Radiat Oncol Biol Phys 36: 105-111, 1996.

114. Wilkins DE, Heller DP and Raaphorst GP: Inhibition of potentially lethal damage recovery by cisplatin in a brain tumor cell line. Anticancer Res 13: 2137-2142, 1993

115. Huang H, Huang SY, Chen TT, Chen JC, Chiou CL and Huang TM: Cisplatin restores p53 function and enhances the radiosensitivity in HPV16 E6 containing SiHa cells. J Cell Biochem 91: 756-765, 2004.

116. Britten RA, Peacock J and Warenius HM: Collateral resistance to photon and neutron irradiation is associated with acquired cis-platinum resistance in human ovarian tumour cells. Radiother Oncol 23: 170-175, 1992.

117. Britten RA, Evans AJ, Allalunis-Turner MJ and Pearcey RG: Effect of cisplatin on the clinically relevant radiosensitivity of human cervical carcinoma cell lines. Int J Radiat Oncol Biol Phys 34: 367-374, 1996.

118. Monk BJ, Burger RA, Parker R, Radany EH, Redpath L and Fruehauf JP: Development of an in vitro chemo-radiation response assay for cervical carcinoma. Gynecol Oncol 87: 193-199, 2002

119. Meyn RE, Meistrich ML and White RA: Cycle-dependent anticancer drug cytotoxicity in mammalian cells synchronized by centrifugal elutriation. J Natl Cancer Inst 64: 1215-1219, 1980.

120. Krishnaswamy G and Dewey WC: Cisplatin induced cell killing and chromosomal aberrations in $\mathrm{CHO}$ cells: treated during $\mathrm{G} 1$ or S phase. Mutat Res 293: 161-172, 1993

121. Turchi JJ, Henkels KM and Zhou Y: Cisplatin-DNA adducts inhibit translocation of the $\mathrm{Ku}$ subunits of DNA-PK. Nucleic Acids Res 28: 4634-4641, 2000.

122. Muggia FM and Fojo T: Platinums: extending their therapeutic spectrum. J Chemother 16 (Suppl 4): 77-82, 2004

123. Dewit L: Combined treatment of radiation and cisdiamminedichloroplatinum (II): a review of experimental and clinical data. Int J Radiat Oncol Biol Phys 13: 403-426, 1987.

124. Kumala S, Niemiec P, Widel M, Hancock $R$ and Rzeszowska-Wolny $\mathrm{J}$ : Apoptosis and clonogenic survival in three tumour cell lines exposed to gamma rays or chemical genotoxic agents. Cell Mol Biol Lett 8: 655-665, 2003.

125. Guchelaar HJ, Vermes I, Koopmans RP, Reutelingsperger CP and Haanen C: Apoptosis- and necrosis-inducing potential of cladribine, cytarabine, cisplatin, and 5-fluorouracil in vitro: a quantitative pharmacodynamic model. Cancer Chemother Pharmacol 42: 77-83, 1998. 
126. Fujita M, Fujita T, Kodama T, Tsuchida T and Higashino K: The inhibitory effect of cisplatin in combination with irradiation on lung tumor cell growth is due to induction of tumor cell apoptosis. Int J Oncol 17: 393-397, 2000.

127. Ostruszka LJ and Shewach DS: The role of cell cycle progression in radiosensitization by $2^{\prime}, 2^{\prime}$-difluoro-2'-deoxycytidine. Cancer Res 60: 6080-6088, 2000.

128. Ruiz van Haperen VW, Veerman G, Eriksson S, Boven E, Stegmann AP, Hermsen M, Vermorken JB, Pinedo HM and Peters GJ: Development and molecular characterization of a 2',2'-difluorodeoxycytidine-resistant variant of the human ovarian carcinoma cell line A2780. Cancer Res 54: 4138-4143, 1994.

129.Peters GJ, Ruiz van Haperen VW, Bergman AM, Veerman G, Smitskamp-Wilms E, van Moorsel CJ, Kuiper CM and Braakhuis BJ: Preclinical combination therapy with gemcitabine and mechanisms of resistance. Sem Oncology 23 (Suppl 10): $16-24,1996$
130. Wang Y, Pantelias GE and Iliakis G: Mechanism of radiosensitization by halogenated pyrimidines: the contribution of excess DNA and chromosome damage in BrdU radiosensitization may be minimal in plateau-phase cells. Int J Radiat Biol 66: 133-142, 1994.

131. Webb CF, Jones GD, Ward JF, Moyer DJ, Aguilera JA and Ling LL: Mechanisms of radiosensitisation in bromodeoxyuridine-substituted cells. Int J Radiat Biol 64: 695-705, 1993

132. Albert JM, Cao C, Kim KW, Willey CD, Geng L, Xiao D, Wang H, Sandler A, Johnson DH, Colevas AD, Low J, Rothenberg ML and Lu B: Inhibition of poly(ADP-ribose) polymerase enhances cell death and improves tumor growth delay in irradiated lung cancer models. Clin Cancer Res 13: 3033-3042, 2007

133. Douglas BG and Fowler JF: The effect of multiple small doses of $\mathrm{x}$-rays on skin reactions in the mouse and a basic interpretation. Radiat Res 66: 401-426, 1976. 